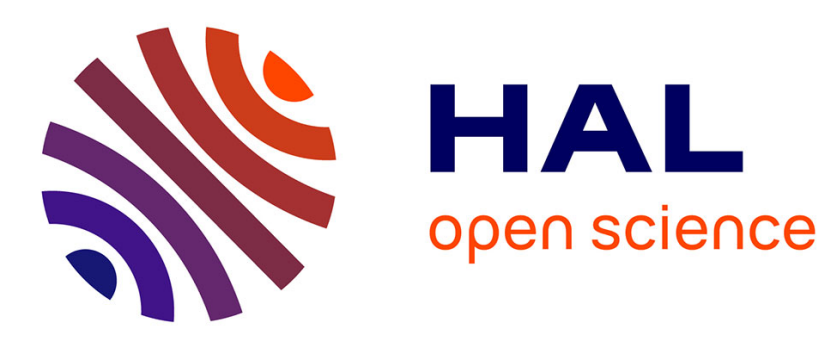

\title{
Satellite-derived shoreline detection at a high-energy meso-macrotidal beach
}

Bruno Castelle, Gerd Masselink, Tim Scott, Christopher Stokes, Aikaterini Konstantinou, Vincent Marieu, Stéphane Bujan

\section{- To cite this version:}

Bruno Castelle, Gerd Masselink, Tim Scott, Christopher Stokes, Aikaterini Konstantinou, et al.. Satellite-derived shoreline detection at a high-energy meso-macrotidal beach. Geomorphology, 2021, 383, pp.107707. 10.1016/j.geomorph.2021.107707 . hal-03411192

\author{
HAL Id: hal-03411192 \\ https://hal.science/hal-03411192
}

Submitted on 2 Nov 2021

HAL is a multi-disciplinary open access archive for the deposit and dissemination of scientific research documents, whether they are published or not. The documents may come from teaching and research institutions in France or abroad, or from public or private research centers.
L'archive ouverte pluridisciplinaire HAL, est destinée au dépôt et à la diffusion de documents scientifiques de niveau recherche, publiés ou non, émanant des établissements d'enseignement et de recherche français ou étrangers, des laboratoires publics ou privés. 


\section{Satellite-derived shoreline detection at a high-energy meso-macrotidal beach}

Bruno Castelle ${ }^{1,2}$, Gerd Masselink ${ }^{3}$, Tim Scott ${ }^{3}$, Christopher Stokes ${ }^{3}$, Aikaterini Konstantinou ${ }^{3}$, Vincent Marieu $^{1,2}$, Stéphane Bujan ${ }^{1,2}$

${ }^{1}$ CNRS, UMR EPOC, Pessac, France

${ }^{2}$ Université de Bordeaux, UMR EPOC, Pessac, France

${ }^{3}$ Coastal Processes Research Group, School of Biological and Marine Sciences, University of Plymouth, Plymouth, UK

Corresponding author: bruno.castelle@u-bordeaux.fr

Highlights

- 35 years of satellite-derived shorelines at a high-energy tidal beach are analysed

- Satellite-derived shoreline proxies are compared with 10 years of field data

- A new approach using wave runup and a threshold on total water level is proposed

- The approach halves shoreline error and doubles the number of usable images

\section{Abstract}

Publicly available satellite imagery can now provide multi-decadal time series of shoreline data from local to global scale, enabling analysis of sandy beach shoreline variability across a spectrum of temporal scales. Such data can, however, be associated with large uncertainties, particularly for beaches experiencing a large tidal range $(>2 \mathrm{~m})$ and energetic incident waves. We use a decade of bimonthly topographic surveys at the high-energy meso-macrotidal beach of Truc Vert, southwest France, and concurrent wave and water-level hindcast to investigate the uncertainties associated with satellite-derived time series of the shoreline position. We show that consideration of the water level and wave runup elevation are critical for accurately estimating waterline position and, in turn, shoreline position. At Truc Vert, including non-tidal water level residuals (e.g. wind-driven surge) and accounting for time- and elevation-varying beach slope for horizontal correction did not improve satellite-derived shoreline position. A new total water level threshold is proposed to maximize the number of usable images while minimizing errors. Accounting for wave runup and the new water level threshold at Truc Vert, the number of usable satellite images is doubled and shoreline position errors are at least halved compared to previous work at this site. Using the 1984-2019 reconstructed shoreline, we also show that the satellite-derived shoreline trends and interannual variability are in better agreement with field measurements. Although the approach proposed here needs to be 
32 tested on other sites in different tidal/wave forcing environments with different morphological and 33 sediment characteristics, we anticipate that it will improve the temporal and spatial description of 34 shoreline change on most surf tidal beaches where accurate continuous water level and wave 35 hindcasts and/or observations are available.

36 Keywords: shoreline change; long-term trend; satellite; wave runup 37 


\section{Introduction}

40

Understanding and predicting shoreline change along sandy coasts is of paramount importance for coastal managers and policy-makers (Stive et al., 2002). Ambient (or background) long-term shoreline change is an essential and sometimes dominant component in models of future shoreline change due to sea-level rise (Vitousek et al., 2017; Vousdoukas et al., 2020; McCarroll et al., 2020). However, shoreline variability occurs across a wide range of time scales and it can be challenging to derive the ambient shoreline change unless very long data time series are available. Shorelines can dramatically erode within hours as a result of storm waves (Harley et al., 2017). At the other end of the spectrum, long-term, multi-decadal shoreline change is driven by various processes such as sealevel rise (Ranasinghe et al., 2012) and coastal sediment supply (Carter et al., 1987). In between, seasonal and interannual shoreline variability is primarily driven by changes in incident wave conditions (Dodet et al., 2019); however, in sectors adjacent to tidal inlets and estuary mouths, fluctuations in ebb-channel morphology can also drive shoreline variability (O'Connor et al., 2011). Anthropogenic forcing, such as beach nourishments or implementation of hard structures that disturb sediment pathways may also have a profound impact on shoreline variability (Turner, 2006). A core issue to improve our understanding and ability to predict shoreline change is therefore to monitor shoreline change at the highest possible frequency and the longest possible time scale on a large range of sandy environments representative of the natural variability (Splinter et al., 2013; Ibaceta et al., 2020; Toimil et al., 2020).

There is a wealth of coastal monitoring techniques employed to survey beach morphology and derive shoreline change. These topographic surveys are often performed by means of GNSS surveys (Baptista et al., 2008). Large-scale GNSS coastal monitoring programs based on widely spaced beach profiles adequately distributed along 10 s to 100 s kilometres are scarce (Wijnberg and Terwindt, 1995; Ludka et al., 2019). Instead, most coastal monitoring programs focus on a single site through representative profiles (e.g., Lee et al., 1998; Suanez et al., 2012; Turner et al., 2016) or detailed digital elevation models (DEMs) along 100s to 1000s of metres (e.g., Stokes et al., 2015; Castelle et al., 2017a), which are typically surveyed monthly or bimonthly. On similar lengths of coastline, the daily shoreline proxy can be inferred from permanent video stations at reasonably low cost over years to decades (e.g., Harley et al., 2011), although associated with lower accuracy. Photogrammetry based on UAV images has also recently emerged as a promising tool to monitor 100 s to 1000 s metres of coast at high spatial resolution (e.g., Laporte-Fauret et al., 2019). Larger scale, say 10 s to 100 s of kilometres, coastal monitoring programs are typically based on Lidar surveys 
(Le Mauff et al., 2018; Nicolae Lerma et al., 2019). However, such surveys are costly and have low repeat frequencies. They are therefore difficult to maintain on the long-term and do not provide insight into seasonal variability.

Publicly available satellite imagery can now be used at no cost to provide short-term to multi-decadal shoreline data from local to global scale using a variety of techniques (e.g., Garcia-Rubio et al., 2015; Liu et al., 2017; Qiao et al., 2018; Douarte et al., 2018; Toure et al., 2019). Long-term (> 30 yrs) global estimation of shoreline erosion and accretion were recently proposed by Luijendijk et al. (2018) and Mentaschi et al. (2018). Although these studies provided unprecedented global insight into shoreline change, a detailed inspection of the satellite-derived trends computed in Luijendijk et al. (2018) at many high-energy and/or meso to macrotidal beaches reveals that many of these trends are not supported by field data and empirical evidence. Although trends appear reliable in sectors where dramatic change is observed (Luijendijk et al., 2018), the discrepancies are obvious primarily in slowly evolving sectors, say less than several metres per year, and at sites with a large intra- and interannual shoreline variability. A more accurate assessment of shoreline change rates is therefore a necessary requirement to develop reliable identification of a global typology of accreting, stable and eroding shores. Furthermore, these computed historical trends can be extrapolated and combined with debatable sea-level-rise impact rule to conclude on shoreline position by the end of the century and potential extinction of half of the world's beaches (Vousdoukas et al., 2020). In addition to addressing the limitations to this approach pointed out in Cooper et al. (2020), such pioneering projective work would gain in reliability by improving the historical shoreline trends, as well as including the effects of potential multi-decadal variability.

Vos et al. (2019a) recognised issues with detecting shorelines using satellite data on dissipative beaches and sites experiencing a large tidal range. After Liu et al. (2017) who showed that tidal effect correction improves satellite-derived shoreline errors, Vos et al. (2019b) tested a tidal correction at a meso-macrotidal site by using a time-invariant characteristic beach face slope and only using images captured at higher stages of the tide. This decreased the shoreline position error by $15 \mathrm{~m}$. No significant improvement in their error statistics was found using slope measurements from the closest survey compared to using the single time-invariant slope value. However, the effects of wave runup on water level at the coast, which can cause large horizontal translation of the waterline and shoreline position under moderate- to high-energy breaking waves, was not considered. Other sources of errors associated with satellite-derived shorelines can also arise, such as for instance through issues with geo-referencing (Schubert et al., 2017) and incorrect delineation of the water/sand interface (Toure et al., 2019). 
Overall, improving satellite-derived shoreline positions and, in turn, shoreline trends is critical to more accurately discriminate accreting, stable and eroding beaches, and to reduce uncertainties in future shoreline change projections in the frame of climate change, both locally and globally. In this paper, we address satellite-derived shoreline evolution at the high-energy and meso-macrotidal beach of Truc Vert, southwest France, using the out-of-the-box open access python-based CoastSat toolkit (Vos et al., 2019a, 2019b). We explore if including astronomical tide, non-tidal water level residuals, wave action and local beach slope can reduce shoreline position uncertainties, and therefore lead to an improved assessment of long-term trends and interannual variability. We also investigate the value of increasing the number of satellite images in the analysis. These results have strong implications from the perspective of global long-term trend computations and further extrapolation until the end of the century, as well as for the assessment of interannual shoreline variability on beaches.

\section{Study area}

The study site is located in southwest France, extending c. $140 \mathrm{~km}$ from the Gironde estuary in the north to Biscarrosse in the south, with a focus on Truc Vert beach (Figure 1a). This sandy coast comprises a large beach-dune system that is only interrupted by the Arcachon lagoon inlet.

The wave climate at these latitudes along the Atlantic coast of Europe is generated in the North Atlantic Ocean, predominantly by eastward-tracking extra-tropical cyclones. Wave conditions at Truc Vert, described below, are based on a numerical wave hindcast detailed in Section 3.2. The incident wave conditions are strongly seasonally modulated with the monthly-averaged significant wave height $H_{s}$, peak wave period $T_{p}$ and angle of wave incidence $\theta$ ranging, respectively, from $1.1 \mathrm{~m}, 8.8 \mathrm{~s}$ and $297^{\circ}$ in summer, to $2.4 \mathrm{~m}, 12.1 \mathrm{~s}$ and $287^{\circ}$ in winter (Figure $2 \mathrm{a}-\mathrm{c}$ ). Thus, larger and longer waves with a more western incidence occur in winter compared to summer. Winter wave activity shows a strong interannual variability, with moderate winters alternating with extreme winters characterised by significant spatial and temporal storm clustering (Masselink et al., 2016). High-energy winters occur as a result of the intensification and southward shift of Azores high / Icelandic low dipole, which is strongly correlated with the West Europe Pressure Anomaly climate index and weakly associated with the North Atlantic Oscillation (Castelle et al., 2017b).

The coast is meso-macrotidal with an annual mean spring tidal range of $3.7 \mathrm{~m}$ and a largest astronomical tidal range of c. $5 \mathrm{~m}$ (Castelle et al., 2017a). Nearshore tide-driven currents are intense $(>1 \mathrm{~m} / \mathrm{s})$ in the vicinity of the Gironde estuary mouth and Arcachon tidal inlet, and are negligible $1<$ $0.2 \mathrm{~m} / \mathrm{s}$ ) compared to wave-driven currents on the open coast that can well exceed $1 \mathrm{~m} / \mathrm{s}$ in rip-cell circulation of under energetic obliquely incident waves. 
The beach sediment consists of medium quartz sand with a median grain size of c. $0.35 \mathrm{~mm}$ and a large spatial variability (Gallagher et al., 2011). Except adjacent to the tidal inlet and estuary mouths, beaches are morphodynamically intermediate, but with a double-bar system. The subtidal outer bar is modally crescentic and a modally transverse bar-rip system characterises the intertidal inner bar system. The inner and outer mean rip spacing is approximately 400 and $700 \mathrm{~m}$, respectively, with large spatial and temporal variability (Castelle et al., 2007; Almar et al., 2010).

Analysis of georeferenced aerial photographs since 1950 showed a large spatial variability of shoreline change within the study area (Castelle et al., 2018). Maximum shoreline dynamics are observed along the sectors adjacent to the Gironde Estuary mouth and Arcachon inlet (Figure 1a), with erosion and accretion alternating on the timescale of decades. In the northern sector near Cape Négade (Figure 1a), the mean erosion rate is largest at c. $5 \mathrm{~m} / \mathrm{yr}$, with a quasi-steady trend. Mean erosion rate decreases southwards to 1-2 m/yr at approximately $30 \mathrm{~km}$ south of Hourtin (Figure 1a). Further south, the coast has been relatively stable over the last 70 years along a c. 20-km long sector. This sector comprises Truc Vert beach (Figure 1a), of which topographic data will be used herein to compare satellite-derived shoreline dynamics.
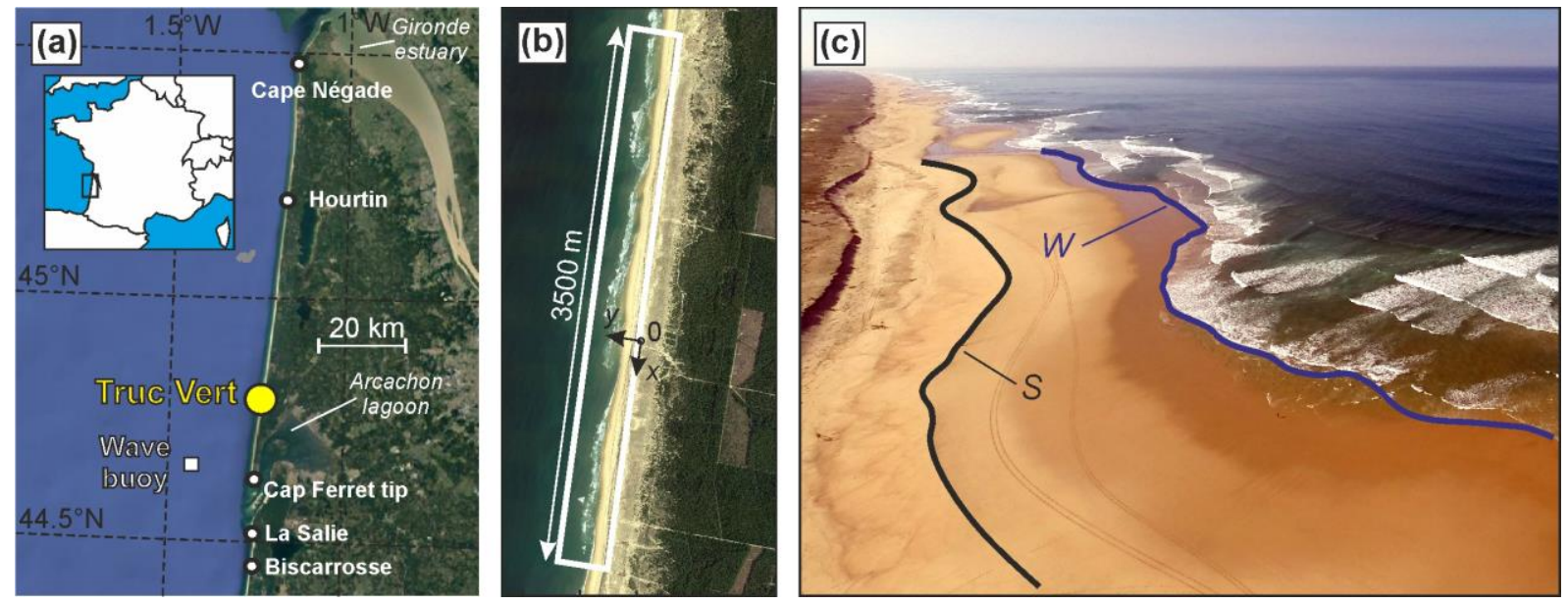

Figure 1. (a) Location map, (b) survey region and reference frame used at Truc Vert beach and (c) aerial view of Truc Vert beach taken between low and mid tide, with indication of water level $(W)$ position and visual estimate of the $1.5-\mathrm{m}$ shoreline proxy $S$, which is the optimal shoreline proxy at Truc Vert (photo: Vincent Marieu). 

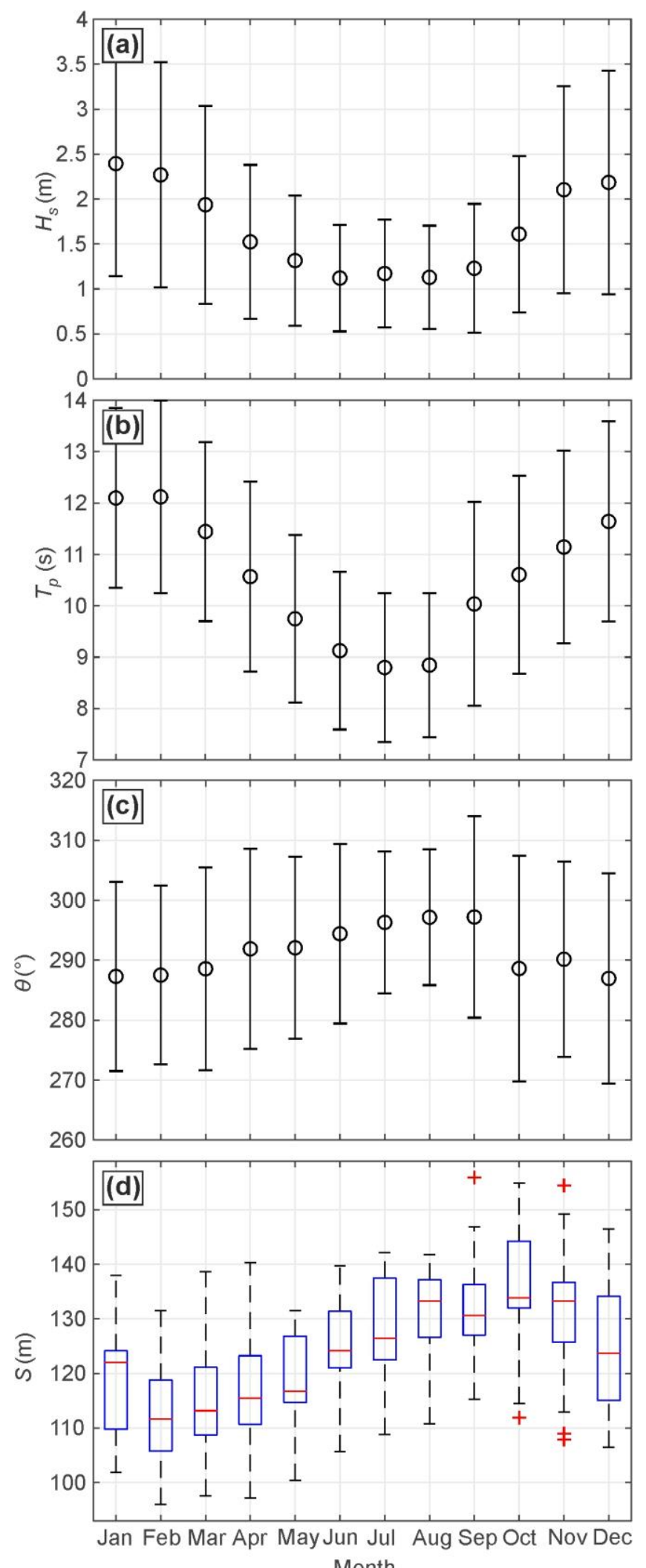

158 Figure 2. Monthly wave statistics offshore of Truc Vert for 2005-2020: (a) significant wave height $H_{s}$; (b) peak wave period $T_{p}$; (c) angle of wave incidence $\theta$; and (d) cross-shore position of the alongshore-averaged 1.5-m elevation shoreline proxy at Truc Vert S. Circles and vertical error bars in $(a-c)$ indicate the monthly mean and the \pm 1 monthly standard deviation, respectively. The central 
162 horizontal mark in (d) indicates the median and the top and bottom edges of the blue boxes indicate 163 the $25^{\text {th }}$ and $75^{\text {th }}$ percentiles, respectively. Maximum whisker length extends up to 1.5 times the 164 interquartile range. Data points beyond these whiskers are considered as outliers and are displayed 165 individually as red crosses.

\section{3. Data and methods}

\subsection{Truc Vert beach surveys}

168 A continuous beach survey program has been operational since 2003 at Truc Vert. The resulting 169 monthly to bi-monthly beach morphology dataset is detailed and made available in Castelle et al. 170 (2020). The alongshore coverage of the surveys increased over time, exceeding $600 \mathrm{~m}$ in 2009 before 171 stabilizing at c. $2200 \mathrm{~m}$ since early 2016 (Figure 3b). Figure 3c shows the time series of 1.5-m elevation shoreline proxy cross-shore position $S_{1.5 m}$, which has been used as the primary shoreline proxy in previous studies (e.g., Castelle et al., 2014; Splinter et al., 2014) as it best correlates with the beach-dune volume (Robinet et al., 2016). It is defined as the intersection of the alongshoreaveraged profile with the 1.5-m AMSL elevation datum, where AMSL is obtained at Truc Vert by substracting $0.4 \mathrm{~m}$ from the French National Geodesic Service (NGF-IGN 69) height (Castelle et al.,

177 2020). In line with earlier work (e.g., D'Anna et al., 2020), the shoreline shows large seasonal cycles 178 with a typical amplitude of c. 30-40 m, with superimposed interannual variability of similar amplitude. In the following, only the topographic data collected from 2009 onwards, which extend more than $600 \mathrm{~m}$ alongshore, will be used for validation of local and alongshore-averaged satellitederived waterline $(\bar{X})$ and shoreline $(\bar{S})$ positions. 

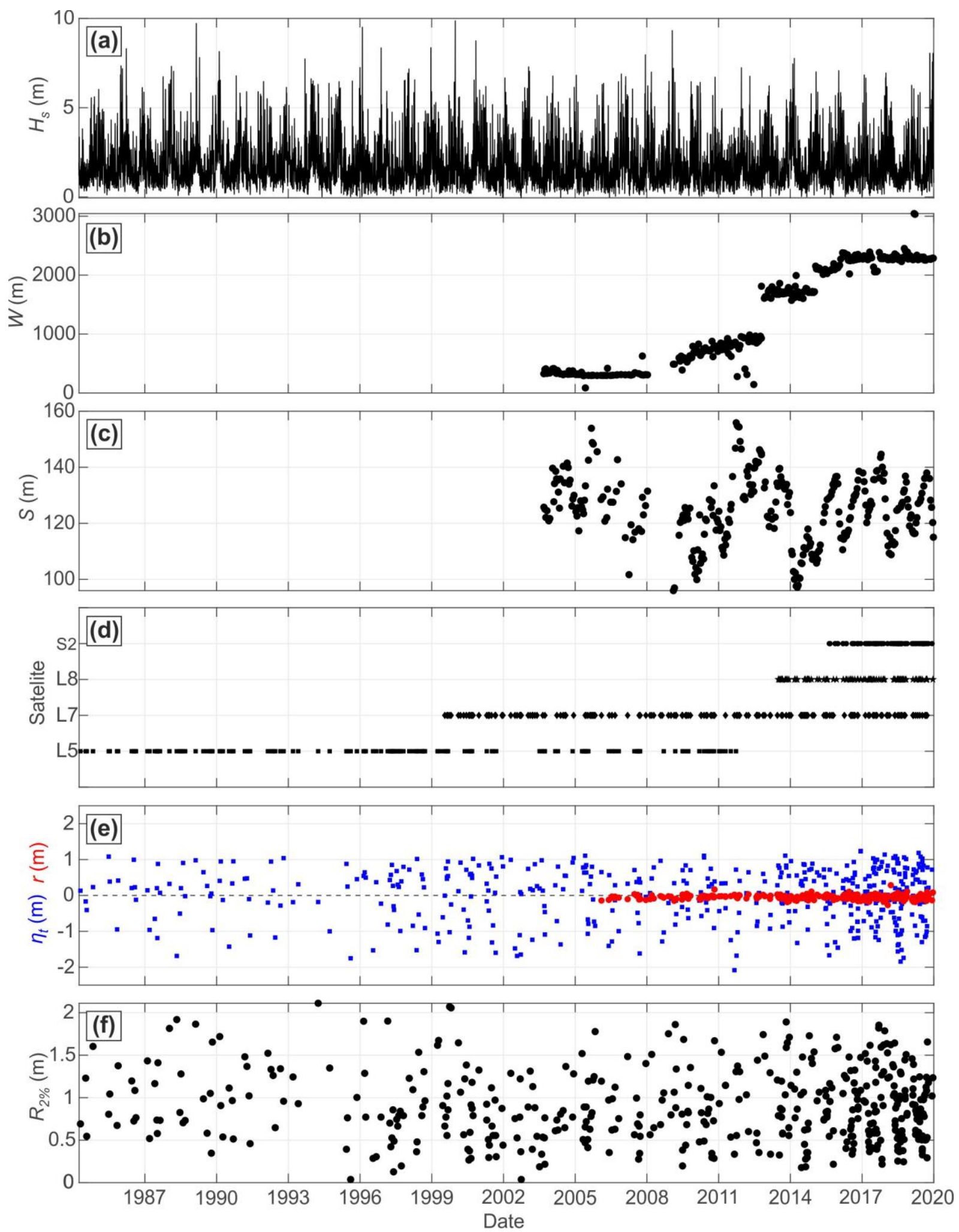

Figure 3. Time series of: (a) significant wave height $H_{s}$; (b) survey alongshore coverage $W$; (c) crossshore location of the alongshore-averaged $1.5-\mathrm{m}$ elevation shoreline proxy $S$ computed from the topographic surveys; (d) usable L5, L7, L8 and S2 satellite images after automatic and visual inspection (see text for details); (e) astronomical tide $\eta_{t}$ estimated from an harmonic analysis of 
2006-2020 MARC hindcast, for which non-tidal residuals $r$ were also extracted; and (f) runup elevation $R_{2 \%}$. All values shown in $(\mathrm{e}, \mathrm{f})$ are given at the satellite flyover time.

\subsection{Wave and water level data}

There is no continuous wave buoy measurements nearby Truc Vert covering the 1984-2019 satellite image period. Instead we used a 26-year (1994-2019) time series of regional wave hindcast (Boudière et al., 2013; Michaud et al., 2015) at the grid point collocated with the Candhis directional wave buoy moored in c. $54 \mathrm{~m}$ depth southwest of Truc Vert (Figure 1a), showing excellent skill against interspersed buoy measurements (see Castelle et al., 2020 for details). To further extend the time series from 1994 back until the early 1980s when the first satellite images were acquired, we used the 1948-2015 wave hindcast described in Masselink et al. (2016), which was validated against the nearby Candhis wave buoy data in Castelle et al. (2014), although with poorer skill than with the 1994-2019 regional wave model.

A 2006-2020 coastal model hindcast of water level (Pineau Guillou, 2013) validated at Truc Vert in Castelle et al. (2020) was used to estimate the water level at the coast. The astronomical tide component $\left(\eta_{t}\right)$ as well as the water level including non-tidal (atmospheric) residuals $r\left(\eta_{t s}=\eta_{t}+r\right)$ were extracted all along the coast in c. $10 \mathrm{~m}$ depth. A harmonic analysis of the 2006-2020 MARC hindcast astronomical tide (no storm surge) was performed to extend the time series of $\eta_{t}$ back until the early 1980 s (Figure 3e).

Breaking waves are responsible for increased water level at the shoreline (Stockdon et al., 2006). We tested many set-up $\zeta$ and runup $R_{2 \%}$ parametrizations, which will be discussed later in the paper. Based on preliminary tests and practical considerations, we used the runup formulation of Sénéchal et al. (2011), specifically calibrated at Truc Vert:

$$
R_{2 \% 6}=2.14 \tanh 0.4 H_{s}
$$

Contrary to many other runup parametrizations (e.g., Stockdon et al., 2006), Equation (1) implies that $R_{2 \%}$ can be scaled using offshore wave height alone at Truc Vert. This is in line with previous observations on highly dissipative beaches (Ruessink et al., 1998; Ruggiero et al., 2001) when infragravity energy dominates runup.

Given that we also considered disregarding any water level variation $\left(\eta=\eta_{0}=0\right)$, in total four combinations of water level $\eta$ at the coast were considered: no water level variation $\left(\eta_{0}\right)$; astronomical tide $\left(\eta_{t}\right)$; astronomical tide $+\operatorname{surge}\left(\eta_{t s}\right)$; astronomical tide $+\operatorname{surge}+\operatorname{runup}\left(\eta_{t s r}\right)$.

\subsection{Publicly available satellite images and waterline detection algorithm}


218 We used the python toolkit CoastSat (Vos et al., 2019b) which is freely-available on GitHub 219 (https://github.com/kvos/CoastSat). The overall approach is described in detail in Vos et al. (2019a). Briefly, the toolkit allows extracting waterlines from publicly available optical satellite data through Google Earth Engine. Landsat 5, 7 \& 8 (L5, L7, L8, 30-m spatial resolution) and Sentinel-2 (S2, 10-m spatial resolution) images are retrieved to a user-defined region of interest before pre-processing to remove cloudy pixels and enhance spatial resolution. A generic waterline detection algorithm is then applied, consisting of two main steps: (1) an image classification into the four classes of 'sand', 'water', 'white-water' and 'other' is performed based on a Neural Network classifier algorithm trained on five training sites along the New South Wales coast; and (2) a sub-pixel resolution border segmentation based on the Modified Normalized Difference Water Index (MNDWI), which is widely used to discriminate water from land features in many applications ( $\mathrm{Xu}, 2006)$. Instead of a global threshold on the MNDWI, a refined threshold that best divides the specific 'sand' and 'water' pixels by maximizing the inter-class variance is used. It provides a more stable and robust waterline boundary through time (Vos et al., 2019a). A sub-pixel resolution contouring algorithm, referred to as Marching Squares (Cipolletti et al., 2012), is then used to compute and map the waterline $W$.

A CoastSat region was defined at Truc Vert, with Figure 4 showing an example Sentinel-2 satellite image (Figure 4a), the corresponding classified image (Figure 4b), MNDWI pixel values (Figure 4c) and the resulting waterline position. Although a total of 1178 satellite images were available at Truc Vert, many images were not useful. For example, more than half of the images were affected by clouds, which resulted in the automatic removal of 361 images exceeding $50 \%$ of cloud cover from the analysis. An additional 339 images were manually removed by visual inspection when the algorithm failed to depict shoreline position for a number of reasons, including: flawed detection of the water/sand limit due to a saturated intertidal domain (Figure 4d) and shadows cast by clouds affecting waterline detection (Figure 4e). Recent Coastsat toolkit development now allows manual adjustment of the waterline by shifting the MNDWI threshold in the MNDWI pixel intensity histogram. However, at the time of using the Coastsat toolkit in the frame of this study, such development was not available but will be addressed in future study. Based on a thorough visual inspection of the images by the operator, a total of 478 Landsat images (including post May 2003 L7 images when Scan Line Corrector failed) and Sentinel images (213 since 2009) were therefore used hereafter at Truc Vert representing the period 1984-2019 (Figure 3d). 

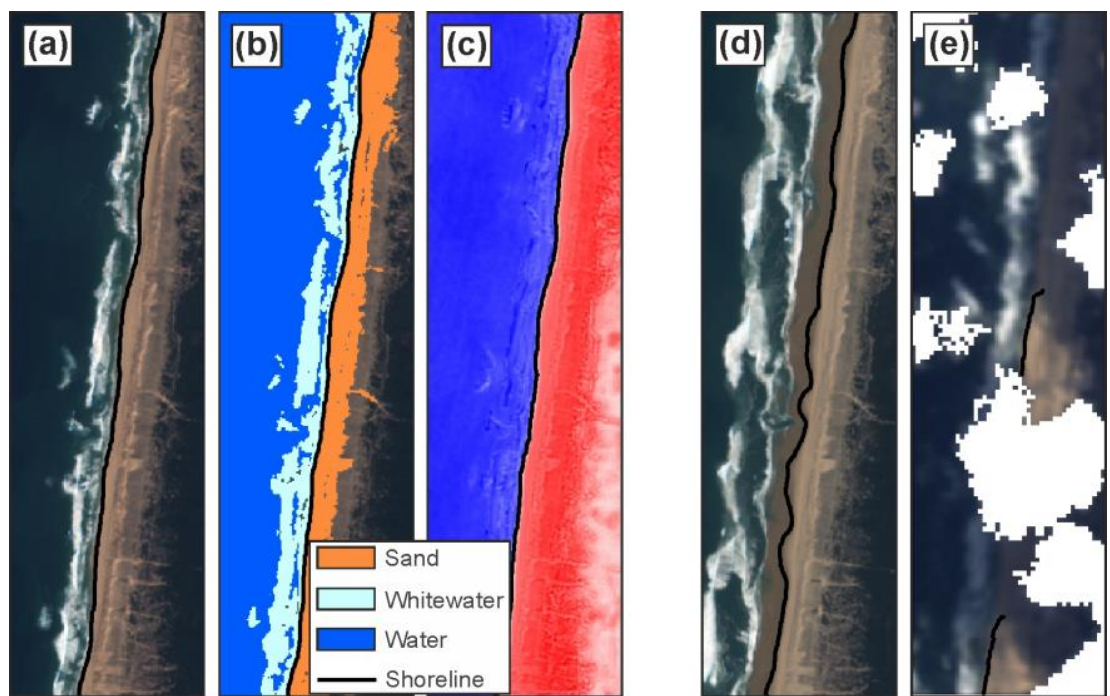

Figure 4. Outputs from the CoastSat tool of Vos (2019b): (a) RGB image of Truc Vert beach from S2 satellite on February 28, 2019; (b) output of image classification where each pixel is labelled as 'sand', 'water', 'white-water' or 'other'; (c) pseudocolor image of the MNDWI pixel values. Examples of images manually disregarded in the analysis: (d) when the algorithm depicted the dry beach limit instead of the waterline due to a saturated intertidal domain (S2 on April 19, 2018); (e) presence of clouds and large casted shadow (L5 on February 23, 1998). In all panels, the black line indicates the waterline detected by CoastSat.

\subsection{Shoreline position computations}

The satellite-derived waterlines were transformed onto the local grid coordinate system. Given that satellite images were taken for a wide range of water levels (Figure 3e) and our interest is in the shoreline position $S$, waterline positions $W$ were projected to $1.5 \mathrm{~m} \mathrm{AMSL}$, which is the most relevant shoreline proxy at Truc Vert as it best correlates with beach-dune volume (Robinet et al., 2016). A water-level correction was applied by translating horizontally the waterline $W$ using a given beach slope $m$ and the water level at the coast $\eta$ at the satellite flyover time:

$$
\Delta y=\frac{\eta-1.5}{m}
$$

where $\Delta y$ is the cross-shore horizontal shift, positive onshore. The four water-level elevations estimations given in Section 3.2 were tested. In addition, while a constant representative slope for Truc Vert of $m=0.05$ was used in line with Vos et al. (2019a), a time- and elevation-dependant slope was also tested here. For the latter, the Truc Vert beach surveys were used to compute the monthly mean beach slope between the $1.5 \mathrm{~m} \mathrm{AMSL}$ elevation and any elevation along the monthly-mean profile (Figure 5). Beach slope computed from the $1.5 \mathrm{~m}$ AMSL elevation to any elevation ranging between $-1.5 \mathrm{~m}$ and $+3 \mathrm{~m} \mathrm{AMSL}$, with end-point slope varying from c. 0.02 to 0.11 . Larger slopes are observed at the upper part of the beach during summer, and more gentle slopes during winter and 

variability (see large bubbles in Figure 5), particularly during summer at the upper part of the beach.

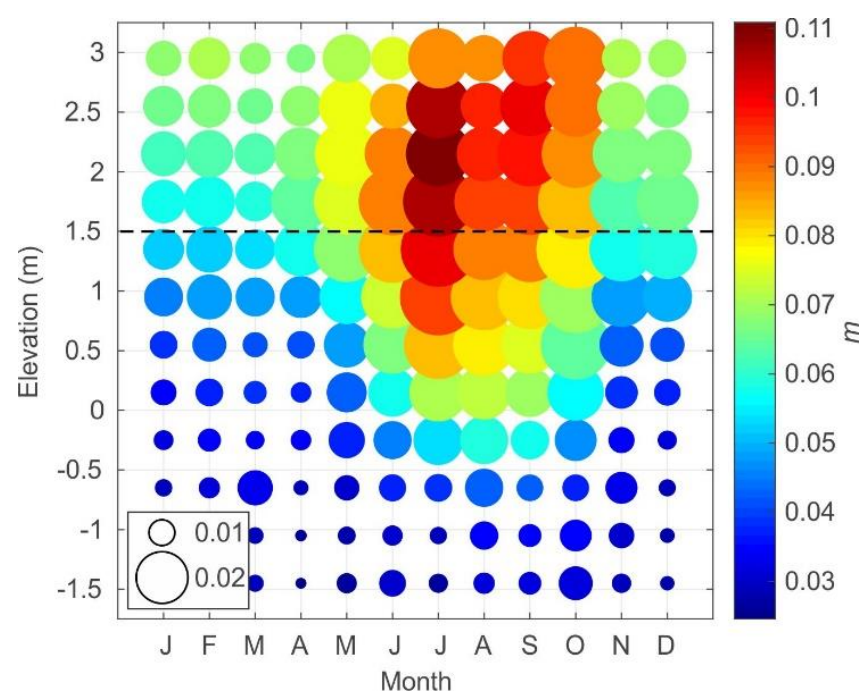

Figure 5. Monthly- and alongshore-averaged beach slope $m$ between a given elevation and the $1.5 \mathrm{~m}$ AMSL elevation, with bubble size indicating the monthly standard deviation.

\section{Results}

\subsection{Waterline detection}

Each satellite-derived waterline, and its cross-shore position Wsat, acquired since 2009 was systematically compared with the theoretical waterline (cross-shore position $W \eta$ ) computed using the Truc Vert beach survey performed closest to the satellite flyover date. For this, all the proxies of water level at the coast $\eta$ detailed in Section 3.1 were projected on the beach survey. Figure 6 shows an example of the Landsat 8 image taken on November 17, 2014, at 10:48 AM GMT, corresponding to incident waves with $H_{s}=2.8 \mathrm{~m}$ near mid-high tide $\left(\eta_{t}=0.76 \mathrm{~m}\right)$ with negligible non-tidal residuals $(<0.01 \mathrm{~m})$ and large runup $\left(R_{2 \%}=1.73 \mathrm{~m}\right)$. CoastSat detects an alongshore non-uniform waterline depicting megacusp embayments enforced by the inner-bar rip channels (Figure 6a-c). This cuspate morphology is also observed on the closest beach topography, which was surveyed three days later on February 20,2019 . The $\eta_{0}(\eta=0)$ elevation iso-contour is located well offshore of the satellitederived waterline (yellow circles in Figure 6d), on average by c. $70.1 \mathrm{~m}$ (Figure 6e). Taking into account the astronomical tide, the $\eta_{t}$ elevation iso-contour is located closer to the satellite-derived waterline (Figure 6d), although still well offshore by c. $43.8 \mathrm{~m}$ (Figure 6f). Given the negligible nontidal residuals at the time of this L8 satellite image, the $\eta_{t s}$ elevation iso-contour essentially superimposes onto that of $\eta_{t}$ (Figure $6 \mathrm{~d}, \mathrm{~g}$ ). In contrast, including wave runup the $\eta_{t s r}$ elevation isocontour is translated landward very close to the satellite-derived waterline (Figure 6d), located onshore by c. $2.0 \mathrm{~m}$ with an alongshore-averaged root mean square error of $3.7 \mathrm{~m}$ (Figure 6h). 

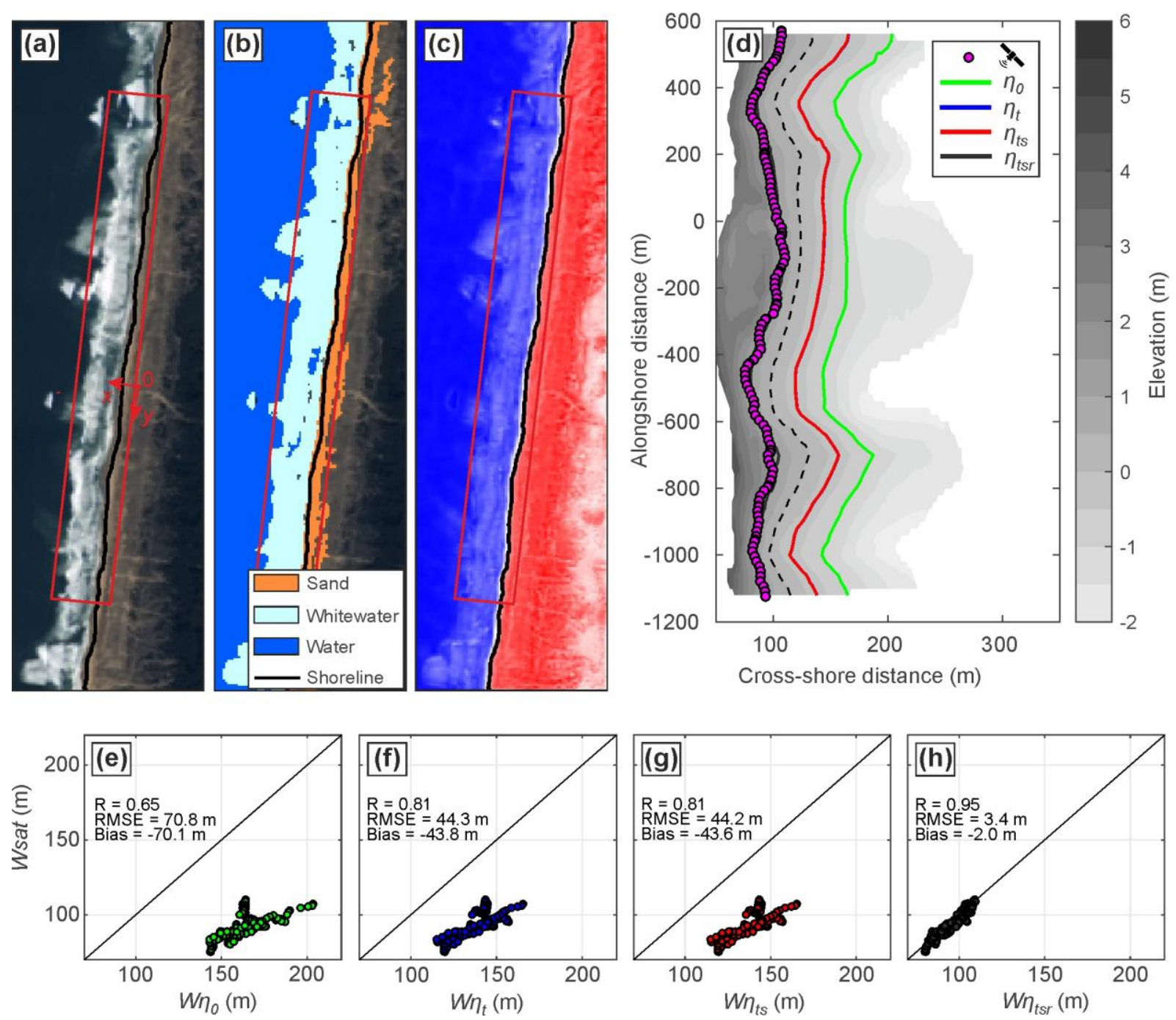

Figure 6. (a-c) Outputs from the CoastSat tool of Vos (2019b) from L8 satellite on November 17, 2014 at 10:48 AM GMT near mid-high tide $\left(\eta_{t}=0.76 \mathrm{~m}\right)$ under energetic waves $\left(H_{s}=2.8 \mathrm{~m}\right)$ with (a) RGB image of Truc Vert beach; (b) output of image classification where each pixel is labelled as 'sand', 'water', 'white-water' or 'other'; and (c) pseudocolor image of the MNDWI pixel values. In (a-c), the red box indicates survey region and reference frame used at Truc Vert beach, and the black line indicates the CoastSat waterline. (d) Truc Vert beach topographic survey on November 10, 2014, with AMSL elevation coloured, superimposed waterline points (magenta dots) detected by CoastSat in (ac) and superimposed iso-contours of elevations: $\eta_{0}(0 \mathrm{AMSL}), \eta_{t}(0.76 \mathrm{~m}), \eta_{t s}(0.76 \mathrm{~m})$ and $\eta_{t s r}(2.50$ $\mathrm{m})$. Note that the $\eta_{t}$ line is hidden behind the $\eta_{t s}$ line due to negligible non-tidal residual, and that the $\eta_{t s r}$ line is partly hidden behind the satellite data points. The dashed black line indicates the 1.5-m elevation iso-contour (shoreline proxy at Truc Vert). Comparison of satellite-derived waterline crossshore positions Wsat against cross-shore positions of iso-contours of elevation (e) $\eta_{0}$, (f) $\eta_{t},(\mathrm{~g}) \eta_{t s}$ and (h) $\eta_{t s r}$ with corresponding correlation (R), root-mean-square error (RMSE) and difference in means (Bias) statistics. 
Table 1 shows the alongshore-averaged waterline cross-shore position $\bar{W} \eta$ statistics for all usable satellite images since 2009 and for each of the 4 proxies of water level $\eta$ at the coast. Using all the images since 2009 ( $n=226$, left-hand column of Table 1), agreement is poor when assuming constant water level at the coast (mean sea level $\bar{W} \eta_{0}, \mathrm{R}^{2}=0.06, \mathrm{RMSE}=29.0$, Bias $=-14.9 \mathrm{~m}$ ). Using astronomical tide $\left(\bar{W} \eta_{t}\right)$ improves the agreement $\left(R^{2}=0.60\right)$, while adding the atmospheric surge component $\left(\bar{W} \eta_{t s}\right)$ does not provide further improvement $\left(\mathrm{R}^{2}=0.59\right)$. In all two situations, the unbiased RMSE (standard deviation STD) and Bias are however still large (STD > 20 m and Bias $<-20$ m). Further adding wave runup to water level iso-contour greatly improves the agreement with CoastSat waterline $\left(\bar{W} \eta_{t s,}, \mathrm{R}^{2}=0.84, \mathrm{STD}=12.4 \mathrm{~m}\right.$, Bias $\left.=3.1 \mathrm{~m}\right)$. Figure 7 further shows that, not surprisingly, errors using $\eta_{0}$ increase as the water level at the time of the satellite flyover deviates from MSL (Figure 7a). In contrast, using astronomical tide $\left(W \eta_{t}\right)$, errors are decreased for higher water levels due to steeper beach and small wave height due to smaller runup, say $\eta_{t s r}>0$ and $H_{s}<1$ $\mathrm{m}$ (Figure 7b), which is the same further adding non-tidal residuals ( $\bar{W} \eta_{t s}$, Figure 7c). Finally, further adding wave runup $\left(\bar{W} \eta_{t s r}\right)$ shows that alongshore-averaged waterline positions are systematically close to that obtained with CoastSat, independent of wave height, for water levels $\eta_{m r}>0.2 \mathrm{~m}$ which is also where the break in slope occurs (Figure 7d). This is reflected in the statistics provided in the middle column of Table1 for $\left(\eta_{t s r}>0.2 \mathrm{~m}, n=164\right)$, showing that, while the coefficient of determination is slightly decreased, STD drops to $7.0 \mathrm{~m}$. A positive Bias is found (7.1 m, Table 1), meaning that the satellite-derived waterline $\bar{W}$ sat is located landward of the theoretical waterline $\bar{W} \eta_{t s r}$, which will be discussed in Section 5. Interestingly, keeping only high-tide images $\left(\eta_{t}>0.5 \mathrm{~m}\right.$ like in Vos et al., 2019a, $n=69$ ), only slightly improves the results (right-hand column of Table 1), but more than halves the number of usable images. At the other end (left-hand column of Table 1), using all the images results in larger correlation $\left(R^{2}=0.84\right)$ and smaller RMSE $(12.8 \mathrm{~m})$. However, STD is almost doubled. These results indicate that, for this study site, using $\eta_{t s r}$ which includes wave runup and selecting images with $\eta_{t s r}>0.2 \mathrm{~m}$ is the optimal strategy that both minimizes alongshoreaveraged waterline position error and maximizes the number of usable satellite images. Finally, it is important to note that these comparisons consider satellite images and beach surveys separated by up to 10 days (Figure 7). Given the large morphological changes occurring at Truc Vert, the errors given here must be considered as conservative.

Table 1. Statistics of alongshore-averaged waterline cross-shore positions $\bar{W} \eta$ for each of the 4 water elevation proxies against alongshore-averaged waterline cross-shore position $\bar{W}$ sat computed with CoastSat, using all satellite images, or selecting only those taken for $\eta_{t s r}>0.2 \mathrm{~m}$ or $\eta_{t}>0.5 \mathrm{~m}$. Only satellite images for which a beach survey was performed within 10 days were considered. 


\begin{tabular}{|c|c|c|c|c|c|c|c|c|c|}
\hline & \multicolumn{3}{|c|}{ All $(n=226)$} & \multicolumn{3}{|c|}{$\eta_{t s r}>0.2 \mathrm{~m}(n=164)$} & \multicolumn{3}{|c|}{$\eta_{t}>0.5 \mathrm{~m}(n=69)$} \\
\hline & $\begin{array}{c}\text { RMSE } \\
\text { (STD) [m] }\end{array}$ & $\begin{array}{l}\text { Bias } \\
{[\mathrm{m}]}\end{array}$ & $R^{2}$ & $\begin{array}{c}\text { RMSE (STD) } \\
{[\mathrm{m}]}\end{array}$ & $\begin{array}{l}\text { Bias } \\
{[\mathrm{m}]}\end{array}$ & $\mathrm{R}^{2}$ & $\begin{array}{c}\text { RMSE (STD) } \\
{[\mathrm{m}]}\end{array}$ & $\begin{array}{l}\text { Bias } \\
{[\mathrm{m}]}\end{array}$ & $\mathrm{R}^{2}$ \\
\hline $\begin{array}{l}\bar{W} \eta_{0}( \\
\mathrm{MSL})\end{array}$ & $29.0(24.8)$ & -14.9 & 0.06 & $30.7(17.5)$ & -24.2 & 0.05 & $34.0(14.1)$ & -30.9 & 0.15 \\
\hline $\bar{W} \eta_{t}$ & $28.9(20.2)$ & -20.7 & 0.60 & $23.4(17.1)$ & -16.0 & 0.26 & $14.5(12.0)$ & -8.1 & 0.28 \\
\hline $\bar{W} \eta_{t s}$ & $31.4(21.1)$ & -23.3 & 0.59 & $26.1(18.7)$ & -18.2 & 0.23 & $15.5(12.6)$ & -9.1 & 0.24 \\
\hline $\bar{W} \eta_{t s r}$ & $12.8(12.4)$ & 3.1 & 0.84 & $10.0(7.0)$ & 7.1 & 0.78 & $10.6(6.0)$ & 8.7 & 0.80 \\
\hline
\end{tabular}



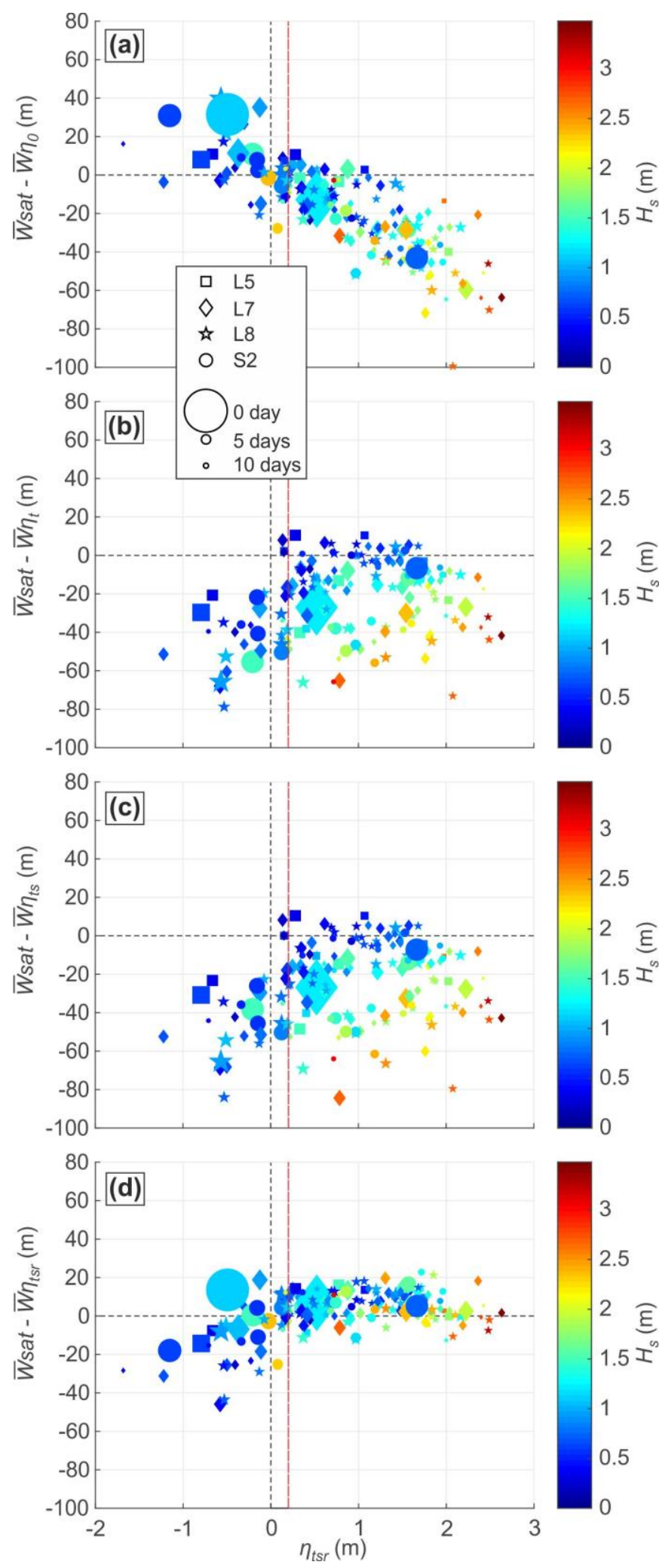

346 Figure 7. Difference between alongshore-averaged iso-contour cross-shore position $(\bar{W} \eta)$ for 347 elevations (a) $\eta_{0}$, (b) $\eta_{t}$, (c) $\eta_{t s}$ and (d) $\eta_{t s r}$ and alongshore-averaged waterline cross-shore position computed with CoastSat $\bar{W}_{\text {sat }}$, positive meaning more landward satellite-derived waterline, against estimated total water level $\eta_{\text {tsr. }}$ In all panels, significant wave height $H_{s}$ is coloured, the vertical dashed red line indicates the $\eta_{t s r}=0.2 \mathrm{~m}$ threshold, symbol indicates the satellite and symbol size is 
proportional to the duration between the satellite image and the closest Truc Vert beach topographic survey used to compute iso-contours.

\subsection{Shoreline position}

Based on the results of the analysis on the role of water level proxies on the alongshore-averaged waterline cross-shore position $\bar{W} \eta$, and to facilitate comparison with earlier work, only four satellitederived shoreline position $(S \eta)$ methods are further considered by translating horizontally a given waterline $W \eta$ using a given beach slope. Below we now disregard elevation $\eta_{t s}$ as non-tidal residuals were found to have negligible impact on waterline position at Truc Vert and address four alongshoreaveraged shoreline position: (1) $\bar{S} \eta_{0}$ ignoring tide; (2) $\bar{S} \eta_{t}$ with tidal correction using water level $\eta_{t}$ and a constant slope ( $m=0.05$ in Equation (2)) as in Vos et al. (2019a); (3) $\bar{S} \eta_{t s r}$ with tidal correction using water level $\eta_{t s r}$ (i.e. including wave runup) and a constant slope $m=0.05$ and (4) $\bar{S} \eta_{t s r}$ with tidal correction using water level $\eta_{t s r}$ (i.e. including wave runup) and the time- and elevation-varying monthly beach slope shown in Figure 5 feeding Equation (2). Figure 8 shows that the poorest agreement with field data is found for $\bar{S} \eta_{0}$ (STD $=22.0 \mathrm{~m}, \mathrm{R}^{2}=0.42$, Figure 8a), although agreement substantially improves when only considering high-tide images $\left(\eta_{t}>0.5 \mathrm{~m} ; \mathrm{STD}=10.9 \mathrm{~m}, \mathrm{R}^{2}=0.64\right.$, Figure 8c). Surprisingly enough, using $\bar{S} \eta_{t}$ for high-tide images does not further improve the results (Figure 8f). Although a direct comparison cannot be performed, Vos et al. (2019a) who used 74 satellite-derived shorelines between 2005-2018 for $\eta_{t}>0.5 \mathrm{~m}$ at a single transect at Truc Vert, found similar results $\left(\mathrm{STD}=12.7 \mathrm{~m}, \mathrm{R}^{2}=0.46\right)$. In contrast, results dramatically improve for $\bar{S} \eta_{t s r}$ (STD $=5.8$ $m, R^{2}=0.86$, Figure $\left.8 i\right)$, meaning that including runup in water level estimation at this coast is key to improve the derived shoreline position. It is important to note that similar agreement is obtained disregarding non-tidal residuals and only including astronomical tide and wave runup (STD $=5.6 \mathrm{~m}, \mathrm{R}^{2}$ $=0.86$, not shown).

Results are not further improved when using a time- and elevation-varying monthly beach slope $\bar{S} \eta_{t s t}\left(\right.$ STD $=6.6 \mathrm{~m}, \mathrm{R}^{2}=0.81$, Figure 8I). This means that, in line with Vos et al. (2019a), further including a presumably better description of beach slope does not necessarily improve the derived shoreline position. While the best results are obtained for $\bar{S} \eta_{t s r}$ for high-tide images, importantly, performance is only marginally less good by including more than twice as many images for $\eta_{t s r}>0.2$ $\mathrm{m}\left(\mathrm{STD}=7.4 \mathrm{~m}, \mathrm{R}^{2}=0.78\right.$ in Figure $\left.8 \mathrm{~h}\right)$. Therefore, using $\bar{S} \eta_{t s r}$ appears as the optimal approach to infer shoreline position by both maximizing the number of usable images leading to improved temporal resolution of the shoreline signal and minimizing spatial error associated with the shoreline estimates. Importantly, a substantial positive $7.1 \mathrm{~m}$ bias is found, meaning that satellite-derived shoreline is located too far seaward, which will be discussed in Section 5. Disregarding non-tidal 
residuals and only considering astronomical tide and wave runup $\left(\bar{S} \eta_{t r}\right)$ gives similar results (STD =

385

386

387

388

389 $7.2 \mathrm{~m}, \mathrm{R}^{2}=0.78$ for $\eta_{t s r}>0.2 \mathrm{~m}$, not shown) to $S \eta_{t s r}$. This emphasizes that astronomical tide and wave runup are key to satellite-derived shorelines, and that, at Truc Vert, non-tidal residuals can be disregarded. Finally, as per the waterline detection, all these errors are considered conservative due to the comparison window $(<10$ days between the satellite image the beach survey used for comparison).
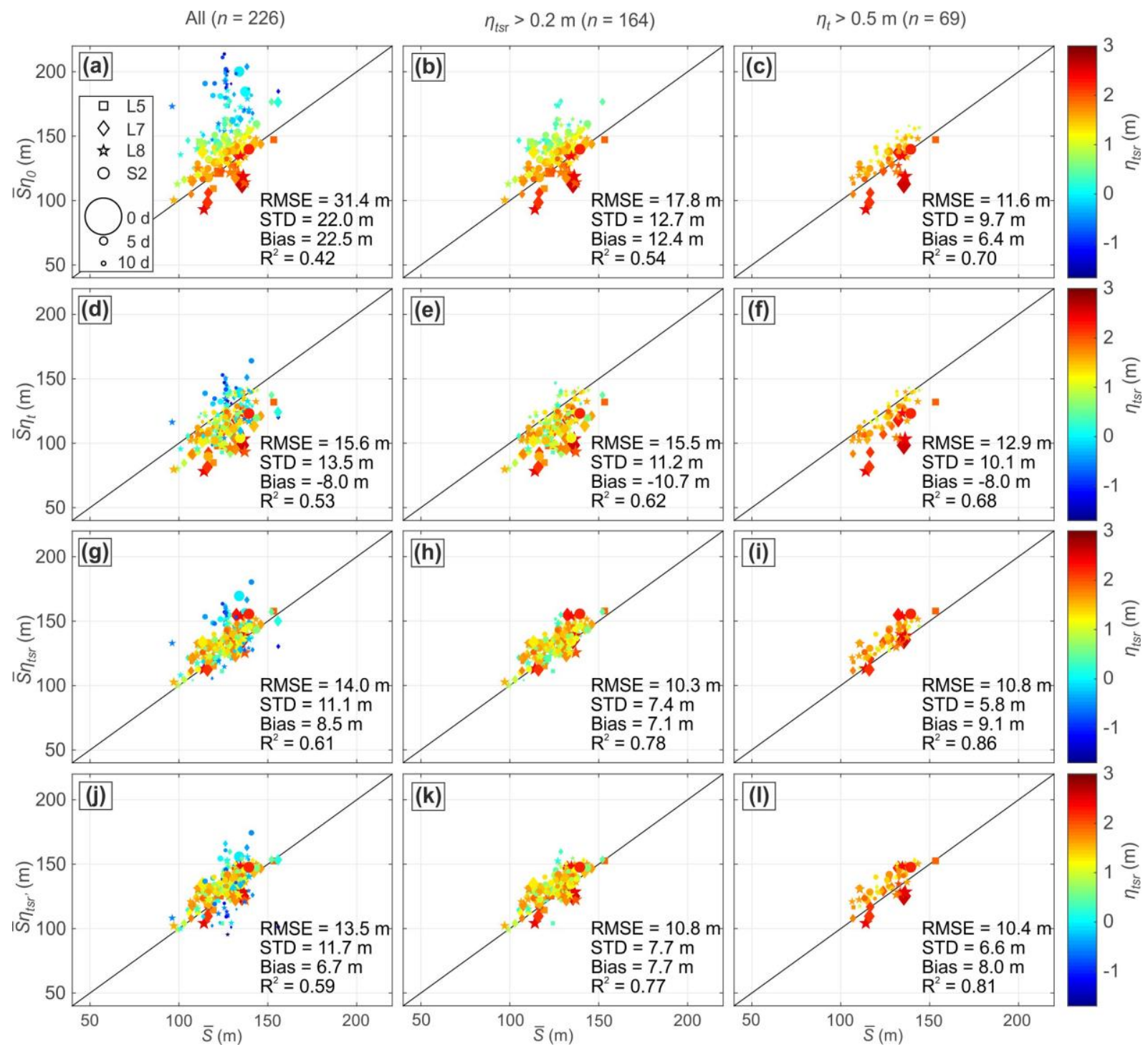

Figure 8. Satellite-derived alongshore-averaged shoreline position against in-situ shoreline position with corresponding statistics using only satellite images for which a beach survey was performed less than 10 days before or after. A positive bias means that satellite-derived shoreline is located too far seaward. The analysis includes (left-hand panels) all usable satellite images since $2009(n=226)$; (middle panels) only satellite images for $\eta_{t s r}>0.2 \mathrm{~m}(n=164)$; and (right-hand panels) only satellite images for $\eta_{t}>0.5 \mathrm{~m}(n=69)$. (a-c) $\bar{S} \eta_{0},(\mathrm{~d}-\mathrm{f}) \bar{S} \eta_{t},(\mathrm{~g}-\mathrm{i}) \bar{S} \eta_{t s r}$ and $(\mathrm{j}-\mathrm{l}) \bar{S} \eta_{t s r r}$. 
Figure 9 shows the time series of alongshore-averaged shoreline position (1.5 m AMSL elevation shoreline proxy) deviation from the mean measured at Truc Vert (S̃) and that derived from satellite images $\tilde{S} \eta_{t s r}$ for images with $\eta_{m r}>0.2 \mathrm{~m}$. The satellite-derived shoreline readily reproduces the seasonal and interannual cycles at Truc Vert, despite a few outliers. The computed 2009-2019 shoreline trends from measurements and satellite are $+0.50 \mathrm{~m} / \mathrm{yr}$ and $+0.57 \mathrm{~m} / \mathrm{yr}$, respectively, therefore showing good agreement. Noteworthy, the trend computed using $\tilde{S} \eta_{0}(n=226)$ and $\tilde{S} \eta_{t}(n$ = 69) is $0.81 \mathrm{~m} / \mathrm{yr}$ and $0.78 \mathrm{~m} / \mathrm{yr}$, respectively, which is substantially larger, but of the same order of magnitude as that derived using $\tilde{S} \eta_{t s r}(n=164)$. Importantly, disregarding non-tidal residuals but keeping runup contribution, 2009-2019 shoreline trend of $\tilde{S} \eta_{t r}$ is $0.63 \mathrm{~m} / \mathrm{yr}$, which is closer to that computed from the topographic surveys.

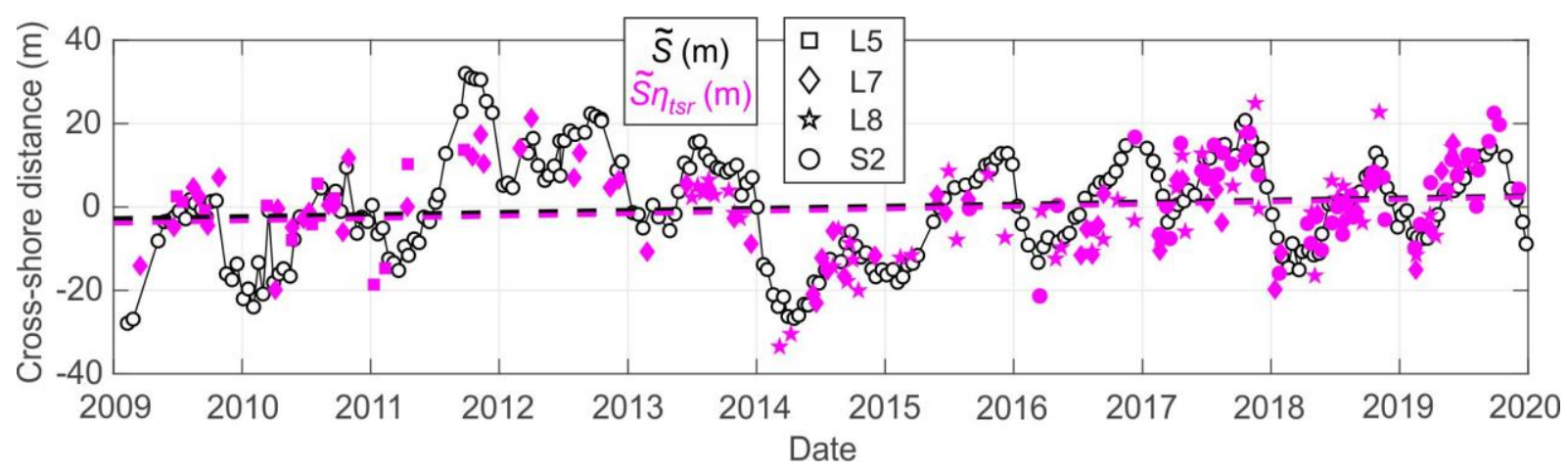

Figure 9. Time-series of shoreline change at Truc Vert beach derived from satellite $\tilde{S} \eta_{t s r}$ compared with in-situ shoreline position $\widetilde{S}$ with superimposed trends (dashed lines).

Figure 10 shows the time series of shoreline deviation from the mean for the entire satellite image dataset, starting from April 21, 1984. Figure 10b shows the results using our optimal approach, which is here disregarding hindcasted non-tidal residuals as they are not available prior to 2006 (and including these did not represent significant improvement anyway). The corresponding $\widehat{S} \eta_{t r}$ longterm trend using images with $\eta_{t r}>0.2 \mathrm{~m}$ is $0.50 \mathrm{~m} / \mathrm{yr}$, which is very similar to that computed for the 2009-2019 period (Figure 10a). The long-term trend computed with shoreline $\tilde{S} \eta_{0}$ is also similar $(+0.60 \mathrm{~m} / \mathrm{yr})$, while that using $\tilde{S} \eta_{t}$ for images with $\eta_{t}>0.5 \mathrm{~m}$ is slightly reduced $(+0.31 \mathrm{~m} / \mathrm{yr})$.

To emphasize interannual variability, we computed the yearly post-winter mean shoreline position from which we subtracted the long-term trend (coloured bars in Figure 10a). The number of usable satellite images increased in time (Figure 3d) from 2 in 1993 and 1994 to 49 in 2018, and also varied seasonally, ranging from 0.34 images per year in January to 1.91 images in June (related to cloud cover). Therefore, in order to maximize the number of post-winter satellite-derived shoreline positions, we systematically averaged all available shoreline data between April and July. Clearly, strong interannual variability is highlighted, with a typical amplitude of $30-40 \mathrm{~m}$, and with the 
2013/2014 winter standing out for all shoreline proxies $\widehat{S} \eta_{t r}$ (Figure 10b). Interannual cycles are more pronounced using $\widehat{S} \eta_{0}$ for all images, with a lot of shoreline outliers (Figure 10a). Interannual cycles for

$428 \tilde{S} \eta_{t}$ and $\tilde{S} \eta_{t r}$ are more similar in patterns, although using $\widetilde{S} \eta_{t}$ for images with $\eta_{t}>0.5 \mathrm{~m}$ does not provide enough post-winter data to address interannual variability prior to the 2000 s due to the lack of available images (Figure 10c). Previous work showed that shoreline inter-annual variability on the open beaches of the Atlantic coast of Europe at these latitudes, and particularly at Truc Vert, is strongly affected by the WEPA index (Dodet et al., 2019). A high negative correlation $(R=-0.82)$ was found between post-winter $\tilde{S} \eta_{t r}$ and winter WEPA index, while correlation drops for $\tilde{S} \eta_{0}(R=-0.50)$ and $\tilde{S} \eta_{t}(R=-0.49)$. This suggests that interannual shoreline variability can be better depicted using 435 $\tilde{S} \eta_{t r}$ for $\eta_{t r}>0.2$
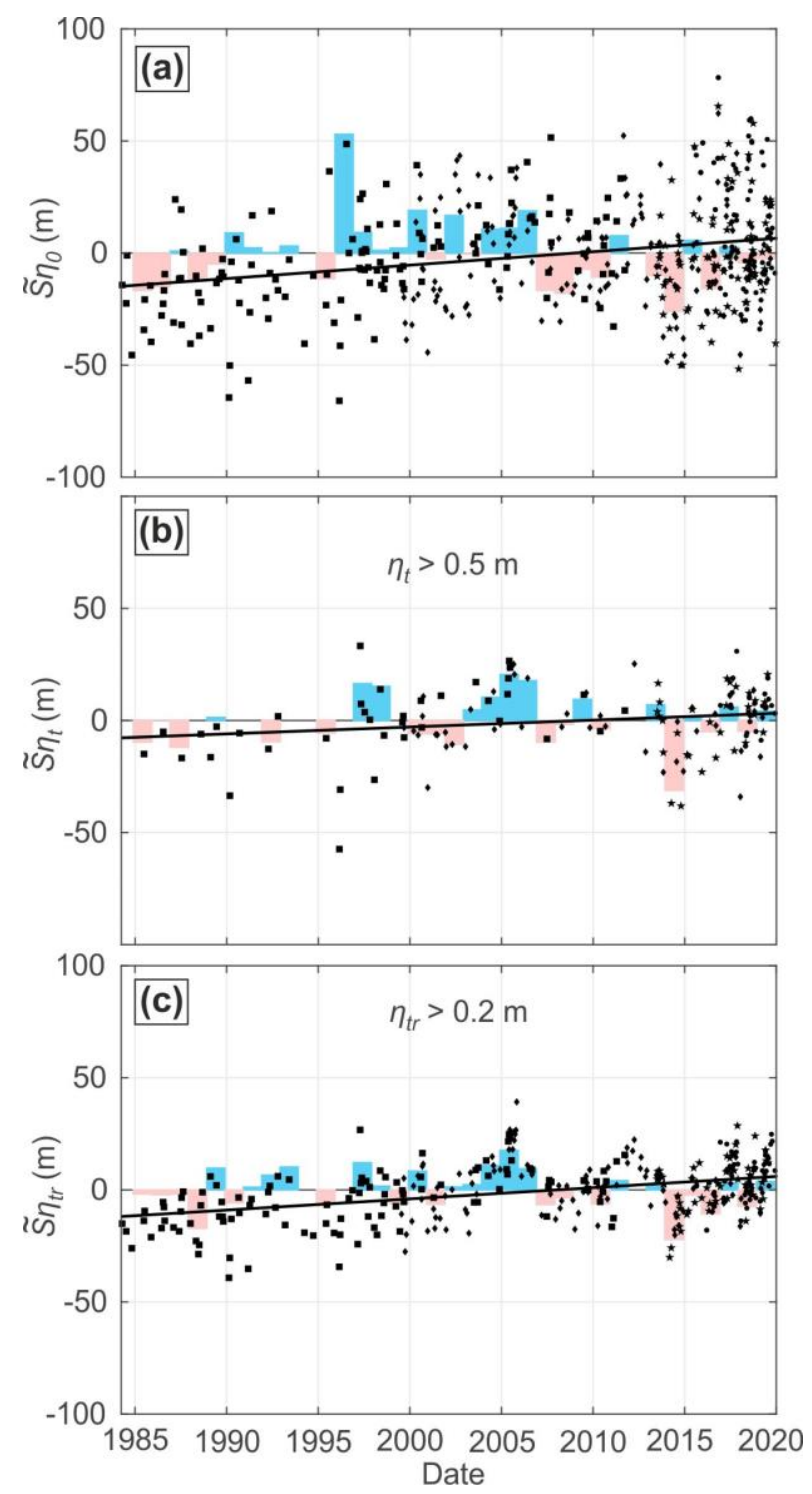

Figure 10. Time-series of satellite-derived shoreline position deviation from the mean at Truc Vert beach, with the coloured bars showing the interannual variability (trend removed) in post-winter 
shoreline position and the solid line depicting long-term trend: (a) $\tilde{S} \eta_{0}$ for all images; (b) $\tilde{S} \eta_{t}$ for images with $\eta_{t}>0.5 \mathrm{~m}$; (c) $\tilde{S} \eta_{t r}$ for images with $\eta_{t r}>0.2 \mathrm{~m}$.

\section{Discussion and conclusions}

442 Our results indicate that, without having to improve the CoastSat satellite-derived waterline 443 algorithm, the estimation of shoreline position, defined as the profile intersection with a given 444 elevation datum, can be greatly improved on a meso-macrotidal high-energy sandy beach. Crucial to 445 this improvement is accounting for the wave runup. This was surprising as it is highly unlikely that 446 most satellite images were taken at maximum runup excursion. Instead it was expected that the 447 wave set-up, defined by the time-averaged water level of the waterline would be a better descriptor 448 of the shoreline position. However, a preliminary analysis showed that wave set-up only slightly improved waterline detection compared with disregarding wave effects. An explanation for this is that because beaches such as Truc Vert tend to remain wet after the passage of a single runup event, the CoastSat algorithm picks-up the interface between the recent runup (wet) and dry sand instead of the sand/water interface. This may also explain why although the variance in waterline position is largely accounted for by including the wave runup component, the average position of the resulting time- and space-averaged waterline is shifted landward by $7.1 \mathrm{~m}$. (Table 1). Improving the waterline detection for such an environment by using the mean runup instead of the $2 \%$ exceedance runup $\left(R_{2 \%}\right)$ will need further investigation. We also tested other set-up and runup formulas, which did not yield better results. For instance, the formulation used here by Sénéchal et al. (2011) resulted in a substantially large inshore bias (runup overestimation) of waterline position compared to other formulas, meaning that runup elevations are possibly overestimated. However, this formulation provided the best variance explanation, which is why it was preferred therein. For instance, using images with $\eta_{t s r}>0.2 \mathrm{~m}$, waterline STD and $\mathrm{R}^{2}$ are $7.0 \mathrm{~m}$ and 0.78 (Table 1), respectively. Results worsen using the runup parametrizations proposed by Stockdon at al. (2006) for intermediate and dissipative beaches, with STD $=8.8 \mathrm{~m}$ and $\mathrm{R}^{2}=0.67$ for the intermediate beach parametrization, and with STD $=8.7 \mathrm{~m}$ and $\mathrm{R}^{2}=0.67$ for the dissipative parametrization. However, waterline estimation using Stockdon et al. (2006) is still greatly improved compared with when wave contribution to water level at the coast is disregarded $\left(\bar{W} \eta_{0}\right.$ and $\bar{W} \eta_{t}$ in Table 1). Our new approach also allows using a lower water level threshold $\left(\eta_{t s r}>0.2 \mathrm{~m}\right)$, greatly increasing the number of useable images available for shoreline change analysis. This improvement is especially important for higher latitudes where more frequent cloud cover significantly reduces the number of cloud-free images. However, this threshold is likely site specific and does not correspond to any salient break in beach slope at Truc Vert. Environmental factors controlling this threshold will need to be addressed by exploring satellite-derived shoreline at other beaches where beach profiles are regularly surveyed. 
Including the non-tidal water level residuals did not improve the results at Truc Vert. However, this is not a generic result as at Truc Vert, and along the entire Aquitaine coast studied here (Figure 1a), the atmospheric surge is quite small (Le Cann, 1990) owing to the quite narrow continental shelf. Atmospheric surge at Truc Vert at all the satellite flyover dates used here ranged from $-0.27 \mathrm{~m}$ to $+0.29 \mathrm{~m}$ with a mean of $-0.05 \mathrm{~m}$ (Figure $3 \mathrm{e}$ ). This is small compared to the wave runup, ranging from $0.17 \mathrm{~m}$ to $1.89 \mathrm{~m}$ with a mean of $0.91 \mathrm{~m}$ (Figure $3 \mathrm{f}$ ), and the meso-macrotidal tide range (Figure 3e). However, including storm surge may be critical to improve shoreline estimation on coasts with small tide range, but potentially large surge due to large and shallow continental shelf. For instance, sea level can rise by metres due to atmospheric surge in the North Sea (Spencer et al., 2015), the Gulf of Mexico (Sheng et al., 2004) or even c. $100 \mathrm{~km}$ north of the study area where the continental shelf becomes much wider and shallower (Bertin et al., 2012). For energetic coasts with similar settings as Truc Vert, overlooking atmospheric surge is acceptable, which is an advantage for practical applications as accurate local surge hindcasts starting back in the 80 s are scarce.

Another important parameter to quantify is the beach slope, which is used in traditional set-up and runup formulas (Stockdon et al., 2006) and for tidal correction (Vos et al., 2019a). Nevertheless, using a time- and space-varying slope does not improve shoreline reconstruction for Truc Vert, which is another advantage for practical application as only an average beach slope value needs to be provided. Recently, Vos et al. (2020) developed a simple and efficient approach to derive beach slope from the same publicly available satellite images, making it possible to compute satellite shoreline position without requiring local topographic data.

Our work has therefore identified key parameters contributing to shoreline error reduction through the development of a robust methodology. These improvements need to be tested at other sites, in particular on reflective gravel and mixed sand-gravel beaches, and ultra-dissipative sandy mega-tidal beaches. Further possibility for uncertainty reduction concerns the georeferencing and the better detection of the sand/water interface. The CoastSat waterline detection algorithm uses an image classification based on a Neural Network trained at five beaches along the New South Wales coast (Vos et al., 2019a). Training a new Neural Network for more representative sites may further improve the sand/water interface detection. Overall, more work is required to identify and further address other key sources of uncertainties, which is beyond the scope of the present paper.

The 35-year shoreline time series at Truc Vert (1984-2019) shows that more accurate assessment of long-term shoreline trends and interannual variability can be computed than was achieved in previous global studies (e.g., Luijendijk et al., 2018; Mentaschi et al., 2018). Similar trends are obtained with $\tilde{S} \eta_{\text {tr }}(+0.50 \mathrm{~m} / \mathrm{yr})$ and $\tilde{S} \eta_{0}(+0.60 \mathrm{~m} / \mathrm{yr})$ (Figure 10b). However, shoreline trend 
computation at other sites along the Aquitaine coast (e.g. Hourtin, Biscarrosse, Figure 1a) indicates that much larger differences can be observed. $\tilde{S} \eta_{0}$, which does not account for water level fluctuations, is close to the global approach in Luijendijk et al. (2018) who used yearly composite and therefore averaged water level variations. A detailed inspection of the trends computed in Luijendijk et al. (2018) at Truc Vert shows trends that are very different to those computed herein. The dominant trend computed by Luijendijk et al. (2018) at Truc Vert indicates, strongly alongshore variable, large, erosion at $-1.13 \mathrm{~m} / \mathrm{yr}$ averaged over the same $3500-\mathrm{m}$ sector, peaking locally at 3.8 m/yr. A strong alongshore variability was also found in Mentaschi et al. (2018), although a direct quantitative comparison could not be performed. This goes against decadal and multi-decadal observations at this coast (e.g., Castelle et al., 2017a, 2018) and results presented herein, which all concur to an alongshore-uniform c. $+0.5 \mathrm{~m} / \mathrm{yr}$ trend. It must be acknowledged that the comparison above is performed between a site-specific analysis where the images were manually selected and a runup correction was applied using a local wave and water level hindcast (our study), and a global method that was applied over the whole world (Luijendijk et al., 2018; Mentaschi et al., 2018).

We therefore anticipate that the new approach proposed here can improve the accuracy of satellite shoreline long-term trends and interannual variability along many coasts worldwide. However, at rapidly evolving sections, improvements will be marginal. North of Truc Vert, at Cape Négade (Figure 1a), the long-term trend is reasonably steady at $-4.63 \mathrm{~m} / \mathrm{yr}$ for $\tilde{S} \eta_{t r}$ (Figure 11a-e), and is very similar with all the other shoreline proxies (not shown). The same applies further south at the tip of the Cap Ferret sand spit or at La Salie at each side of the Arcachon Lagoon tidal inlet, where large long-term trends of $+3.34 \mathrm{~m} / \mathrm{yr}$ and $-8.38 \mathrm{~m} / \mathrm{yr}$ are computed, respectively. However, large cycles are observed with some dramatic decadal trends. For instance, the shoreline at La Salie has been eroding by nearly $30 \mathrm{~m} / \mathrm{yr}$ over the last seven years (Figure 11k), despite an overall positive shoreline trend since the 1980s. Therefore, except at Cape Négade, where chronic erosion is relatively steady, further extrapolating these 35-year trends to estimate shoreline position by 2100 (Vousdoukas et al., 2020) is questionable, because time scales of shoreline cycles are similar to the period of satellite data availability. 


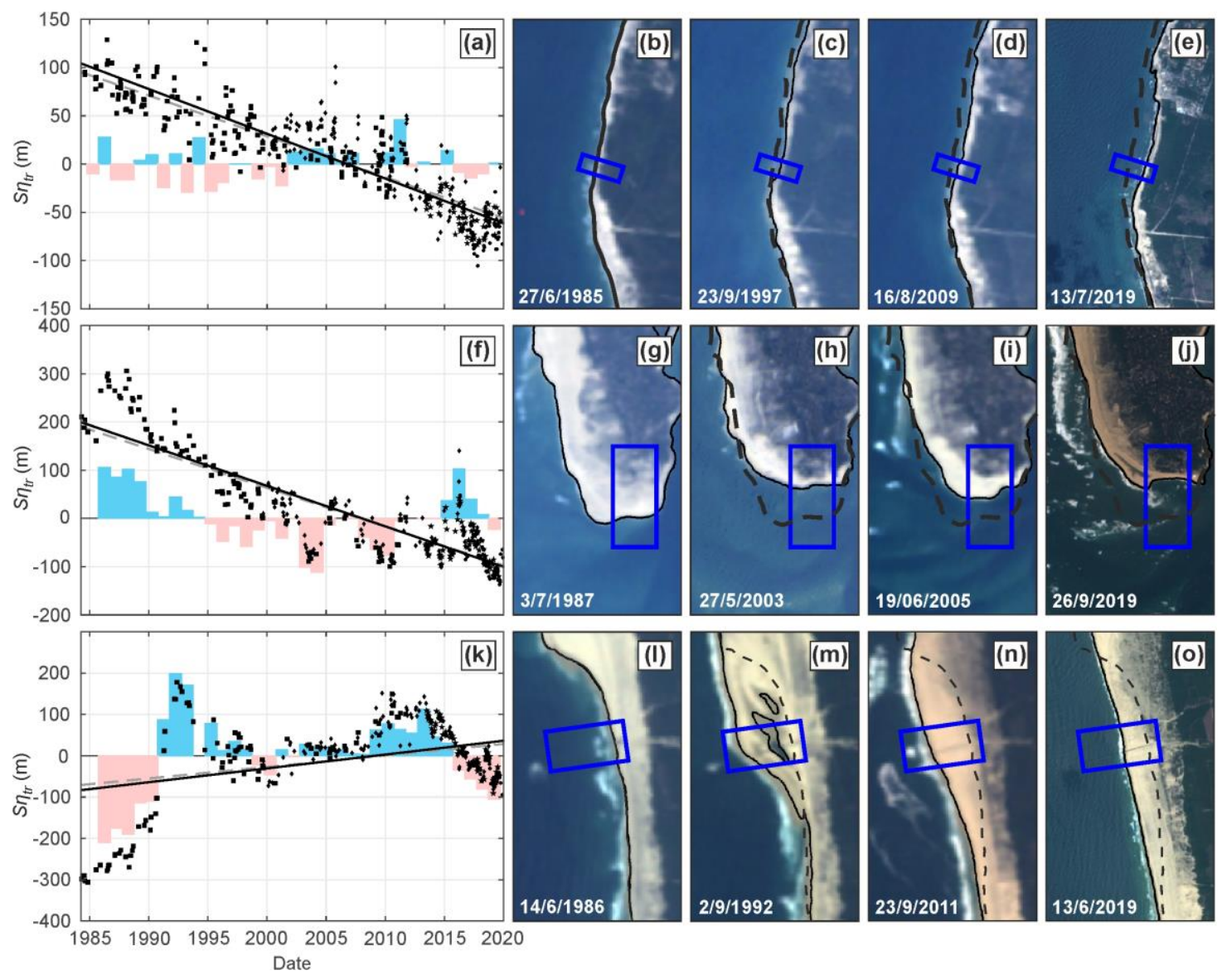

534 Figure 11. Left-hand panels: time series of shoreline position at (a) Cape Négade, (f) Cap Ferret 535 sandspit tip and (k) la Salie (see location map in Figure 1a) derived from satellite $\tilde{S} \eta_{t r}$. In the left536 hand panels the linear shoreline trend for $\tilde{S} \eta_{t r}$ is indicated by the black dotted line. The coloured 537 bars in $(a, b)$ show the inter-annual variability (trend removed) in post-winter shoreline position. 538 Right-hand panels: corresponding RGB images at different relevant stages of evolution, blue boxes 539 indicate areas where shoreline positions were averaged alongshore to compute the time series 540 shown in the left-hand panels.

541 We acknowledge that the concept of global application is very attractive and responds to strong 542 demand. However, past shoreline trends estimations on beaches incurs large uncertainties, which 543 become exacerbated if extrapolated in time to estimate future shoreline change. Vos et al. (2019a) 544 recognised issues with dissipative and large tidal range sites. This work has identified key parameters 545 contributing to large errors for this type of environment and developed a robust methodology for 546 limiting uncertainty. Such approach requires accurate tide and inshore wave hindcasts, which can be 547 challenging to obtain in complex coastal settings where, e.g., wave shadowing from offshore islands 548 or offshore wave refraction can largely impact breaking wave conditions. These improvements need 549 to be tested in other sites with similar tidal/wave forcing characteristics but different morphological 550 and sediment characteristics. This will allow addressing the links between coastal response and large- 
scale climate patterns of atmospheric variability in a wide range of environments. It will also provide improved beach state classification and, where time scales of shoreline cycles are not similar to the period of data availability (e.g. away from inlet and estuary mouths), less uncertain shoreline projections by the end of the century in the context of climate change.

\section{Acknowledgments}

BC, VM and SB funded by Agence Nationale de la Recherche (ANR) grant number ANR-17-CE01-0014; GM and TS funded by the NERC BLUEcoast project (NE/N015525/1); CS and AK funded by Coastal and Marine Applied Research. This study includes the monitoring site of Truc Vert labelled by the Service National d'Observation (SNO) Dynalit (https://www.dynalit.fr). The Observatoire de la Côte Aquitaine (OCA) and Observatoire Aquitain des Sciences de l'Univers (OASU) provide additional financial support for the surveys. NORGAS-UG wave hindcast data provided by LOPS-Ifremer. French Centre d'Archivage National de Données de Houle In Situ (CANDHIS) buoy network operated by French Centre d'Etudes et d'expertise sur les Risques, l'Environnement, la Mobilité et l'Aménagement (CEREMA). GM and TS were supported and partly funded by the UK Natural Environment Research Council (NE/M004996/1; BLUE-coast project). CS and AK were supported by the Coastal and Marine Applied Research consultancy.

\section{References cited}

Almar, R., Castelle, B., Ruessink, B.G., Sénéchal, N., Bonneton, P., Marieu, V., 2010. Two- and threedimensional double-sandbar system behaviour under intense wave forcing and a mesomacro tidal range. Continental Shelf Research, 30, 781-792.

Baptista, P., Bastos, L., Bernardes, C., Cunha, T., Dias, J., 2008. Monitoring Sandy Shores Morphologies by DGPS-A Practical Tool to Generate Digital Elevation Models. Journal of Coastal Research, 24, 1516-1528, doi:10.2112/07-0861.1.

Bertin, X., Bruneau, N., Breilh, J.F., Fortunato, A.B., Karpytchev, M., 2012. Importance of wave age and resonance in storm surges: The case Xynthia, Bay of Biscay. Ocean Modelling, 42, 16-30, doi:10.1016/j.ocemod.2011.11.001.

Boudière, E., Maisondieu, C., Ardhuin, F., Accensi, M., Pineau-Guillou, L., Lepesqueur, J., 2013. A suitable metocean hindcast database for the design of Marine energy converters. International Journal of Marine Energy, 3-4, 40-52, doi:10.1016/j.ijome.2013.11.010

Carter, R.W.G., Johnston, T.W., McKenna, J., Orford, J.D., 1987. Sea-level, sediment supply and coastal changes: Examples from the coast of Ireland. Progress In Oceanography, 18(1-4), 79101. 
Castelle, B., Bonneton, P., Dupuis, H., Sénéchal, N., 2007. Double bar beach dynamics on the highenergy meso-macrotidal French Aquitanian Coast: a review. Marine Geology, 245, 141-159.

Castelle, B., Marieu, V., Bujan, S., Ferreira, S., Parisot, J.P., Capo, S., Senechal, N., Chouzenoux, T., 2014. Equilibrium shoreline modelling of a high-energy meso-macrotidal multiple-barred beach. Marine Geology, 347, 85-94.

Castelle, B., Bujan, S., Ferreira, S., Dodet, G., 2017a. Foredune morphological changes and beach recovery from the extreme 2013/2014 winter at a high-energy sandy coast. Marine Geology, 385, 41-55.

Castelle, B., Dodet, G., Masselink, G., Scott, T., 2017b. A new climate index controlling winter wave activity along the Atlantic coast of Europe: The West Europe Pressure Anomaly. Geophysical Research Letters, 44 (3), 1384-1392.

Castelle, B., Guillot, B., Marieu, V., Chaumillon, E., Hanquiez, V., Bujan, S., Poppeschi, C., 2018. Spatial and temporal patterns of shoreline change of a $280-\mathrm{km}$ long high-energy disrupted sandy coast from 1950 to 2014: SW France. Estuar. Coast. Shelf Sci. 200, 212-223.

Castelle, B., Marieu, V., Bujan, S., Ferreira, S., 2020. 16 years of topographic surveys of rip-channelled high-energy meso-macrotidal sandy beach. Scientific Data, 7, 410, doi:10.1038/s41597-02000750-5.

Cipolletti, M.P., Delrieux, C.A., Perillo, G.M.E., Cintia Piccolo, M., 2012. Superresolution border segmentation and measurement in remote sensing images. Comput. Geosci., 40, 87-96, doi:10.1016/j.cageo.2011.07.015.

Cooper, J. A.G., Masselink, G., Coco, G., Short, A.D., Castelle, B., Rogers, K., Anthony, E., Green, A.N., Kelley, J.T., Pilkey, O.H., Jackson, D.W.T., 2020. Sandy beaches can survive sea-level rise. Nature Climate Change, 10 (11), 993-995, doi:10.1038/s41558-020-00934-2.

D'Anna, M., Castelle, B., Idier, D., Le Cozannet, G., Rohmer, J., Robinet, A., 2020. Impact of model free parameters and sea-level rise uncertainties on 20-years shoreline hindcast: the case of Truc Vert beach (SW France). Earth Surface Processes and Landforms, 45(8), 1895-1907, doi:10.1002/esp.4854

Dodet, G., Castelle, B., Masselink, G., Scott, T., Davidson, M., Floc'h, F., Jackson, D.W.T., Suanez, S., 2019. Beach recovery from extreme storm activity during the $2013 / 14$ winter along the Atlantic coast of Europe. Earth Surface Processes and Landforms, 44(1), 393-401.

Duarte, C.R., De Miranda, F.P., Landau, L., Souto, M.V.S., Sabadia, J.A.B., Da Silva, C.A., Rodrigues, L.I.D.C., Damasceno, A.M., 2018. Short-time analysis of shoreline based on RapidEye satellite images in the terminal area of Pecem Port, Ceara, Brazil. International Journal of Remote Sensing, 39, 4376-4389. 
Gallagher, E.L., MacMahan, J.H., Reniers, A.J.H.M., Brown, J., Thornton, E.B., 2011. Grain size variability on a rip-channeled beach. Marine Geology 1-4, 43-53.

Garcia-Rubio, G., Huntley, D., Russell, P., 2015. Evaluating shoreline identification using optical satellite images. Marine Geology, 359, 96-105, doi:10.1016/j.margeo.2014.11.002.

Harley, M.D., Turner, I.L., Short, A.D., Ranasinghe, R., 2011. Assessment and integration of conventional, RTK-GPS and image-derived beach survey methods for daily to decadal coastal monitoring. Coastal Engineering 58, 194-205.

Harley, M.D., Turner, I.L., Kinsela, M.A., Middleton, J.H., Mumford, P.J., Splinter, K.D., Phillips, M.S., Simmons, J.A., Hanslow, D.J., Short, A.D., 2017. Extreme coastal erosion enhanced by anomalous extratropical storm wave direction. Scientific Reports, 7: 6033.

Hurrell, J.W., 1995. Decadal Trends in the North Atlantic Oscillation: Regional Temperatures and Precipitation. Science, 269, 676-679.

Ibaceta, R., Splinter, K.D., Harley, M.D., \& Turner, I.L., 2020. Enhanced Coastal Shoreline Modeling Using an Ensemble Kalman Filter to include Nonstationarity in Future Wave Climates. Geophysical Research Letters, 47(22), doi.org/10.1029/2020GL090724

Laporte-Fauret, Q., Marieu, V., Castelle, B., Michalet, R., Bujan, S., Rosebery, D., 2019. Low-Cost UAV for High-Resolution and Large-Scale Coastal Dune Change Monitoring Using Photogrammetry. Journal of Marine Science Engineering, 7:63, doi: 10.3390/jmse7030063.

Le Cann, B., 1990. Barotropic tidal dynamics of the Bay of Biscay shelf: observations, numerical modelling and physical interpretation. Continental Shelf Research, 10 (8), 723-758.

Lee, G.H., Nicholls, R.J., Birkemeier, W.A., 1998. Storm-driven variability of the beach-nearshore profile at Duck, North Carolina, USA, 1981-1991. Mar. Geol. 148 (3), 163-177.

Le Mauff, B., Juigner, M., Ba, A., Robin, M., Launeau, P., Fattal, P., 2018. Coastal monitoring solutions of the geomorphological response of beach-dune systems using multi-temporal LiDAR datasets (Vendée coast, France), Geomorphology, 304,121-140, doi :10.1016/j.geomorph.2017.12.037.

Liu, Q., Trinder, J., Turner, I.L., 2017. Automatic super-resolution shoreline change monitoring using Landsat archival data: a case study at Narrabeen-Collaroy Beach, Australia. Journal of Applied Remote Sensing, 11, 016036, doi:10.1117/1.JRS.11.016036.

Luijendijk, A., Hagenaars, G., Ranasinghe, R., Baart, F., Donchyts, G., Aarninkhof, S., 2018. The State of the World's Beaches. Scientific Reports, 8(1), doi:10.1038/s41598-018-24630-6.

Ludka, B.C., Guza, R.T., O’Reilly, W.C., Merrifield, M.A., Flick, R.E., Bak, A.S., Hesser, T., Bucciarelli, R., Olfe, C., Woodward, B., Boyd, W., Smith, K., Okihiro, M., Grenzeback, R., Parry, L., Boyd, G.,2019. Sixteen years of bathymetry and waves at San Diego beaches. Sci Data 6, 161, doi:10.1038/s41597-019-0167-6. 
McCarroll, R.J., Masselink, G., Valiente, N.G., Scott, T., Wiggins, M., Kirby, J., Davidson, M., 2020. A novel rules-based shoreface translation model for predicting future coastal change: ShoreTrans. Doi:10.31223/osf.io/y4kmv

Masselink, G., Castelle, B., Scott, T., Dodet, G., Suanez, S., Jackson, D., Floc'h, F., 2016. Extreme wave activity during 2013/2014 winter and morphological impacts along the Atlantic coast of Europe. Geophysical Research Letters, 43, 2135-2143, doi: 10.1002/2015GL067492.

Mentaschi, L., Vousdoukas, M.I., Pekel, J.-F., Voukouvalas, E., Feyen, L., 2018. Global long-term observations of coastal erosion and accretion. Scientific Reports, 8, 12876, doi:10.1038/s41598-018-30904-w.

Michaud, H., Pasquet, A., Baraille, R., Leckler, F., Aouf, L., Dalphinet, A., Huchet, M., Roland, A., Dutour-Sikiric, M., Ardhuin, F., Filipot, J.F, 2015. Implementation of the new French operational coastal wave forecasting system and application to a wave-current interaction study. 14th International Workshop on Wave Hindcasting and Forecasting \& 5th Coastal Hazard Symposium, Nov. 8-13, Key West, Florida, USA.

Nicolae-Lerma, A., Ayache, B., Ulvoas, B., Paris, F., Bernon, N., Bultreau, T., Mallet, C., 2019. Pluriannual beach-dune evolutions at regional scale: Erosion and recovery sequences analysis along the Aquitaine coast based on airborne LiDAR data. Continental Shelf Research. 189, 103974.

O'Connor, M.C., Cooper, J.A.G., Jackson, D.W.T., 2017. Decadal behavior of tidal inlet-associated beach systems, Northwest Ireland, in relation to climate Forcing. Journal of Sedimentary Research, 81 (1), 38-51. doi: 10.2110/jsr.2011.3.

Pianca, C., Holman, R.A., Siegle, E., 2015. Shoreline variability from days to decades: Results of longterm video imaging. Journal of Geophysical Research-Oceans, 120, 2159-2178.

Pineau-Guillou, L., 2013. PREVIMER. Validation des modèles hydrodynamiques 2D des côtes de la Manche et de Itlantique.

ODE/DYNECO/PHYSED/2013-05. https://archimer.ifremer.fr/doc/00157/26800/

Qiao, G., Mi, H., Wang, W., Tong, X., Li, Z., Li, T., Liu, S., Hong, Y., 2018. 55-year (1960-2015) spatiotemporal shoreline change analysis using historical DISP and Landsat time series data in Shanghai, International Journal of Applied Earth Observation, 68, 238-251, doi: 10.1016/j.jag.2018.02.009.

Ranasinghe, R., Callaghan, D. Stive, M.J.F., 2012. Estimating coastal recession due to sea level rise: beyond the Bruun rule. Clim. Chan., 110, 561-574.

Robinet, A., Castelle, B., Idier, D., Le Cozannet, G., Déqué, M., Charles, E., 2016. Statistical modeling of interannual shoreline change driven by North Atlantic climate variability spanning 20002014 in the Bay of Biscay. Geo-Marine Letters, 36, 479-490. 
Ruessink, B.G., Kleinhans, M.G., Van den Beukel, P.G.L., 1998. Observations of swash under highly dissipative conditions. Journal of Geophysical Research, 103, 3111-3118.

Ruggiero, P., Komar, P.D., Marra, J.J., McDougal, W.G., Beach, R.A., 2001. Wave runup, extreme water levels and the erosion of properties backing beaches. Journal of Coastal Research, 17, 407-419.

Schubert, A., Miranda, N., Geudtner, D., Small, D., 2017. Sentinel-1A/B Combined Product Geolocation Accuracy. Remote Sensing, 9(6), 607, doi:10.3390/rs9060607.

Senechal, N., Coco, G., Bryan, K.R., and Holman, R.A., 2011. Wave runup during extreme storm conditions, Journal of Geophysiscal Research, 116, C07032, doi:10.1029/2010JC006819.

Sheng, Y.P., Zhang, Y., Paramygin, V.A., 2004. Simulation of storm surge, wave, and coastal inundation in the Northeastern Gulf of Mexico region during Hurricane Ivan in 2004. Ocean Modelling, 35(4), 314-331, doi:/10.1016/j.ocemod.2010.09.004.

Spencer, T., Brooks, S.M., Evans, B.R., Tempest, J.A., Möller, I., 2015. Southern North Sea storm surge event of 5 December 2013: Water levels, waves and coastal impacts. Earth-Science Reviews, 146, 120-145, doi:10.1016/j.earscirev.2015.04.002.

Splinter, K., Turner, I.L., Davidson, M.A., 2013. How much data is enough? The importance of morphological sampling interval and duration for calibration of empirical shoreline models. Coastal Engineering, 77, 14-27, doi:10.1016/j.coastaleng.2013.02.009

Splinter, K.D., Turner, I.L., Davidson, M.A., Barnard, P., Castelle, B., Oltman-Shay, J., 2014. A generalized equilibrium model for predicting daily to interannual shoreline response. Journal of Geophysical Research - Earth Surface, 119, 1936-1958, doi:10.1002/2014JF003106.

Stive, M.J.F., Aarninkhof, S.G.J., Hamm, L., Hanson, H., Larson, M., Wijnberg, K.M., Nicholls, R.J., Capobianco, M., 2002. Variability of shore and shoreline evolution. Coastal Engineering, 47(2), 211-235, doi:10.1016/S0378-3839(02)00126-6.

Stockdon, H.F., Holman, R.A., Howd, P.A., Sallenger, A.H., 2006. Empirical parameterization of setup, swash, and runup. Coastal Engineering, 53, 573-588, doi:10.1016/j.coastaleng.2005.12.005.

Stokes, C., Davidson, M. Russell, P., 2015. Observation and prediction of three-dimensional morphology at a high-energy macrotidal beach. Geomorphology 243, 1-13.

Suanez, S., Cariolet, J.M., Cancouët, R., Ardhuin, F., Delacourt, C., 2012. Dune recovery after storm erosion on a high-energy beach: Vougot Beach, Brittany (France). Geomorphology, 139-140, 16-33, doi:10.1016/j.geomorph.2011.10.014.

Toimil, A., Camus, P., Losada, I.J., Le Cozannet, G., Nicholls, R., Idier, D., Maspataud, A., 2020. Climate change-driven coastal erosion modelling in temperate sandy beaches methods and uncertainty treatment. Earth Science Reviews, 202, 103110, doi:10.1016/j.earscirev.2020.103110. 
Toure, S., Diop, O., Kpalma, K., Maiga, A.S., 2019. Shoreline Detection using Optical Remote Sensing: A Review. ISPRS Int. J. Geo-Inf., 8(2), 75, doi:10.3390/ijgi8020075.

Turner, I.L., 2006. Discriminating Modes of Shoreline Response to Offshore-Detached Structures. Journal of Waterway, Port, Coastal, and Ocean Engineering, 132(3), 180-191.

Turner, I.L., Harley, M.D., Short, A.D., Simmons, J.A., Bracs, M.A., Phillips, M.S., Splinter, K.D., 2016. A multi-decade dataset of monthly beach profiles and inshore wave forcing at Narrabeen, Australia. Scientific Data, 2, 160024.

Vitousek, S., Barnard, P.L., Limber, P., Erikson, L., Cole, B., 2017. A model integrating longshore and cross-shore processes for predicting long-term shoreline response to climate change. Journal of Geophysical Research Earth Surface, 122, 782-806, doi:10.1002/2016JF004065.

Vos, K., Harley, M.D., Splinter, K.D., Simmons, J.A., Turner, I.L., 2019a. Sub-annual to multi-decadal shoreline variability from publicly available satellite imagery. Coastal Engineering, doi:10.1016/j.coastaleng.2019.04.004.

Vos, K., Splinter, K.D., Harley, M.D., Simmons, J.A., Turner, I.L., 2019b. CoastSat: A Google Earth Engine-enabled Python toolkit to extract shorelines from publicly available satellite imagery. Environmental Modelling \& Software, 122, 104528, doi:10.1016/j.envsoft.2019.104528.

Vos, K., Harley, M.D., Splinter, K.D., Walker, A., Turner, I.L., 2020. Beach Slopes From Satellite-Derived Shorelines. Geophysical Research Letters, 47, e2020GL088365, doi:10.1029/2020GL088365

Vousdoukas, M.I., Ranasinghe, R., Mentaschi, L., Plomartis, T.A., Athanasiou, P., Luijendyk, A., Feyen, L., 2020. Sandy Beaches under threat of erosion. Nature Climate Change, 10, 260-263, doi:10.1048/s41558-020-0697-0.

Wijnberg, K.M. \& Terwindt, J.H., 1995. Extracting decadal morphological behaviour from highresolution, long-term bathymetric surveys along the Holland coast using eigenfunction analysis. Marine Geology 126, 301-330.

Wiggins, M., Scott, T., Masselink, G., Russell, P., McCarroll, R.J., 2019. Coastal embayment rotation: Response to extreme events and climate control, using full embayment surveys. Geomorphology, 327, 385-403, doi:10.1016/j.geomorph.2018.11.014.

$\mathrm{Xu}, \mathrm{H} ., 2006$. Modification of normalised difference water index (NDWI) to enhance open water features in remotely sensed imagery. Int. J. Remote Sens. 27, 3025-3033, doi:10.1080/01431160600589179. 